\title{
Structure-Specific Endonucleases and the Resolution of Chromosome Underreplication
}

\author{
Benoît Falquet ${ }^{1,2}$ (D) and Ulrich Rass $3, *$ (i) \\ 1 Friedrich Miescher Institute for Biomedical Research, Maulbeerstrasse 66, CH-4058 Basel, Switzerland; \\ benoit.falquet@fmi.ch \\ 2 Faculty of Natural Sciences, University of Basel, Petersplatz 10, CH-4003 Basel, Switzerland \\ 3 Genome Damage and Stability Centre, School of Life Sciences, University of Sussex, Falmer, \\ Brighton BN1 9RQ, UK \\ * Correspondence: u.w.rass@sussex.ac.uk
}

Received: 22 February 2019; Accepted: 13 March 2019; Published: 19 March 2019

\begin{abstract}
Complete genome duplication in every cell cycle is fundamental for genome stability and cell survival. However, chromosome replication is frequently challenged by obstacles that impede DNA replication fork (RF) progression, which subsequently causes replication stress (RS). Cells have evolved pathways of RF protection and restart that mitigate the consequences of RS and promote the completion of DNA synthesis prior to mitotic chromosome segregation. If there is entry into mitosis with underreplicated chromosomes, this results in sister-chromatid entanglements, chromosome breakage and rearrangements and aneuploidy in daughter cells. Here, we focus on the resolution of persistent replication intermediates by the structure-specific endonucleases (SSEs) MUS81, SLX1-SLX4 and GEN1. Their actions and a recently discovered pathway of mitotic DNA repair synthesis have emerged as important facilitators of replication completion and sister chromatid detachment in mitosis. As RS is induced by oncogene activation and is a common feature of cancer cells, any advances in our understanding of the molecular mechanisms related to chromosome underreplication have important biomedical implications.
\end{abstract}

Keywords: DNA replication; chromosome stability; replication stress; Holliday junction resolvase; structure-specific nuclease; ultrafine anaphase bridge; chromosome segregation; mitotic DNA synthesis; genome stability

\section{Introduction}

DNA replication requires the unwinding of the parental DNA duplex by the replicative helicase, which leads to the formation of branched DNA structures that are known as replication forks (RFs). Each parental DNA single-strand then acts as a template for DNA synthesis by DNA polymerases, which associate at RFs with large protein assemblies that are known as replisomes. During a human cell cycle, replisomes routinely synthesize DNA with a combined length of approximately two meters, consisting of billions of base pairs. Along the way, the replisomes have to negotiate numerous obstacles, including DNA damage, DNA secondary structures, proteins bound to the DNA template or sites of active transcription. Such obstacles can impede RF progression, causing replication stress (RS). This is mitigated by the replication checkpoint, which activates the pathways for RF recovery and promotes the resumption of DNA synthesis. RF recovery is critically dependent on homologous recombination (HR) and frequently entails the formation of branched DNA intermediates, notably Holliday junctions (HJs) [1,2], which physically link sister chromatids. These HR intermediates are removed by HJ dissolution along a decatenation pathway that is dependent on a complex of Bloom's syndrome helicase (BLM) and TopoIII $\alpha$-RMI1-RMI2 (Sgs1 helicase and Top3-Rmi1 in yeast) [3]. Alternatively, 
replication-associated HR intermediates can be nucleolytically resolved by a class of structure-specific endonucleases (SSEs) that are known as HJ resolvases [4]. In addition, the cells rely on these same SSEs to cleave chromosomes at sites of potential sister chromatid non-disjunction arising from persistent replication intermediates [5]. This nucleolytic intervention, which leads to chromosome breakage, may appear to be drastic but helps to reinitiate DNA synthesis along HR-dependent repair pathways and serves as a failsafe mechanism for mitotic chromosome segregation. In this review, we provide an overview of the actions of the SSEs Mus81-Mms4/MUS81-EME1 or MUS81-EME2 (budding yeast/human), Slx1-Slx4/SLX1-SLX4 and Yen1/GEN1, highlighting their roles in mitigating genome instability and cell death that results from RS and unfinished DNA replication.

\section{Intrinsic Safeguards Against Chromosomal Underreplication}

Genome replication is a robust process. Eukaryotes have evolved a number of features that help to drive chromosomal replication to completion and minimize the need for SSE interventions [6-8]. Chromosomes are subdivided into replication units-or replicons-each initiated at an origin of replication that gives rise to bidirectional RFs. With the exception of the very tips of chromosomes, each inter-origin space is thus replicated by two converging RFs that have adjacent origins. This set-up compensates for local replication shortfalls caused by RF arrest through the actions of oncoming, neighboring RFs. A non-random origin distribution in yeast suggests that the inter-origin distances have been evolutionarily minimized, which reduces the risk of RF double-stalling events (inactivating a pair of converging forks) that may jeopardize replication completion [9]. Secondly, only a fraction of available replication-competent (licensed) origins are normally activated during the $S$ phase of the cell cycle. This overabundance of licensed origins provides cells with a large pool of dormant origins that serve as failsafe replication initiation sites within the areas of insufficient RF progression. The contribution of dormant origins to bulk DNA synthesis is exemplified by the persistence of replication intermediates into the $\mathrm{M}$ phase, genome instability and tumor formation in mice upon the experimental depletion of dormant origins and in models with ineffective origin firing $[10,11]$. Consistently, excess origins have been shown to activate under replication stress conditions, protecting cells from underreplication and DNA damage [12-15]. Thirdly, the genome of higher eukaryotes is partitioned into multi-replicon replication domains [16]. Origins within a domain activate as a group but with distinct timing from those in other replication domains. This limits the number of active RFs at any one time during $S$ phase, preventing RF destabilization and DNA damage caused by the exhaustion of replication factors or deoxyribonucleoside triphosphate pools (dNTPs) [17,18].

Other safety mechanisms couple DNA replication to cell-cycle progression and ensure that enough time has passed to synthesize a copy of the genome before the cells undergo mitosis. From yeast to humans, mitotic kinase activity is attenuated while DNA replication is ongoing and cells that are unable to initiate DNA replication due to experimental intervention subsequently enter mitosis prematurely [19-23]. This has been linked to a basal activity of the apical checkpoint kinase ATR (Mec1 and Rad3 in Saccharomyces cerevisiae and Schizosaccharomyces pombe, respectively) in response to single-stranded DNA exposed at active RFs. As a consequence, the expression of the mitotic gene network is suppressed and this avoids premature mitotic entry and carryover of underreplicated DNA into mitosis [24-26].

\section{Preventing Underreplication in the Face of Replication Stress}

Replication stress sets off additional cellular pathways that promote full genome replication. While unperturbed replication mildly activates ATR, RS provokes a full-blown ATR response and replication/S-phase checkpoint activation through the exposure of long stretches of RPA-coated single-stranded DNA and single-stranded/double-stranded DNA junctions at stalled RFs. After this, ATR and its orthologues in yeast act with their effector kinases CHK1 and Rad53 in budding yeast and Cds1 in fission yeast to stabilize RFs, upregulate dNTP supplies, modify the DNA replication program and control cell-cycle progression [27,28]. Across organisms, the inhibition of ATR makes 
cells extremely sensitive to RS and unable to avoid frequent chromosome breakage at intrinsically difficult-to-replicate sites [29-33]. In budding yeast, Mec1-Rad53 signaling prevents RF collapse and promotes stable replication across damaged DNA templates $[34,35]$ while checkpoint disruption results in chromosomal underreplication and accumulation of pathological DNA replication intermediates in the presence of RS [36,37]. Similar observations of RF inactivation and underreplication have been made in vertebrate cells that are acutely deprived of ATR activity $[25,26]$. RF collapse in yeast and human cells mediated by nucleases and helicases, including Mus81/MUS81, Exo1/EXO1 and SMARCAL1, in the absence of a functional replication checkpoint indicates that the regulation of DNA metabolic enzymes-including SSEs-is one way in which the checkpoint contributes to replication completion under RS conditions [38-43]. In addition, origin firing is restrained along the ATR-CHK1 axis across organisms $[16,17,44-46]$. Interestingly, the activation of the replication checkpoint attenuates origin firing globally but the origins at sites of ongoing replication maintain their ability to fire [12,45-47]. This limits the number RFs globally when cells experience RS, reducing the risk of excessive RF stalling and DNA-damage formation. At the same time, local origin activation within replicons or replication domains that are already affected by RF blockage promotes replication completion, which further benefits from critical resources (dNTPs, limiting replication factors) not being diverted to sites of newly initiated DNA synthesis in other parts of the genome [48]. Finally, replication checkpoint signaling antagonizes cell-cycle progression by dampening cyclin-dependent kinase (CDK) activity, preventing mitotic entry as long as the unresolved replication problems persist $[27,28,49-54]$.

\section{Structure-Specific Endonucleases and Their Roles in Protecting Cells from Chromosomal Underreplication}

Despite the safeguards described above, accidental RF inactivation and collapse are unavoidable and routinely give rise to branched DNA intermediates that require the attention of SSEs. Cells enter the $S$ phase with a large yet finite number of usable replication origins. It follows that double fork-failures affecting pairs of converging RFs without the possibility of compensatory origin firing in the intervening segments of DNA cannot be fully excluded. HR-dependent RF recovery (explained in more detail below) offers possibilities for re-initiating DNA synthesis and SSEs are involved in the timely removal of recombination intermediates that link sister chromatids [5]. On the other hand, theoretical considerations and experimental evidence indicate that the incidence of double-fork failure increases with genome size such that at least one unreplicated genomic site routinely persists until after bulk DNA synthesis in human cells [55,56]. While ongoing replication activity delays mitosis [24-26], replication completion appears not to be under stringent checkpoint control and segments of unreplicated DNA can thus be carried forth into mitosis [57]. After this, SSEs can intervene by processing persistent replication intermediates. Their actions resolve DNA entanglements at underreplicated chromosomal segments, which otherwise manifest as ultrafine anaphase bridges (UFBs) between segregating sister chromatids [58-61]. UFBs are strongly induced by RS and often localize to chromosomal fragile sites (CFSs), which are characterized by a number of features that make them difficult to replicate, such as being transcriptionally active, poor in usable origins and containing repetitive DNA sequences prone to DNA secondary-structure formation [32,33,62]. Fragile site expression-the appearance of metaphase chromosome gaps and breaks-is thought to be the cytogenetic manifestation of extremely late replication and perturbed chromosome condensation at intrinsically difficult-to-replicate, underreplicated chromosomal sites [62-66]. Importantly, fragile sites demarcate the breakpoints of recurrent chromosome rearrangements seen in cancer cells and give rise to deletions and duplications $[31,67,68]$. Therefore, SSEs play multiple roles in facilitating the completion of genome replication and suppressing genome instability associated with RF failure, incomplete replication and improper chromosome segregation. 


\section{Structure-Specific Endonucleases: Substrate Spectrum and Cell-Cycle Regulation}

Mus81-Mms4/MUS81-EME1 or MUS81-EME2, Slx1-Slx4/SLX1-SLX4 and Yen1/GEN1 are three SSEs implicated in removing branched DNA intermediates that arise from stalled and broken RFs in eukaryotes [5] (Figure 1). Their shared ability to cleave DNA four-way junctions places them in the operationally-defined class of $\mathrm{HJ}$ resolvases [4]. The resolvases recognize the structure of HJs and catalyze the unique reaction that introduces symmetrically-related incisions across the junction branch point. This reaction completes HR processes by separating the recombining DNA duplexes into nicked duplex products, which can be repaired by simple nick ligation [4]. In contrast to the classic resolvase RuvC from bacteria [69], the eukaryotic HJ resolvases exhibit additional DNA debranching activities on DNA flap structures and DNA three-way junctions that are similar to RFs. Moreover, their actions are tightly regulated by post-translational modifications, protein-protein interactions and nucleocytoplasmic shuttling [70].
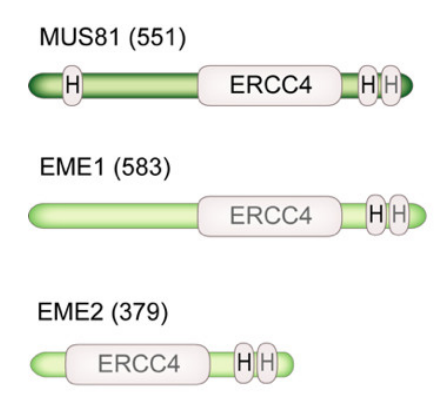
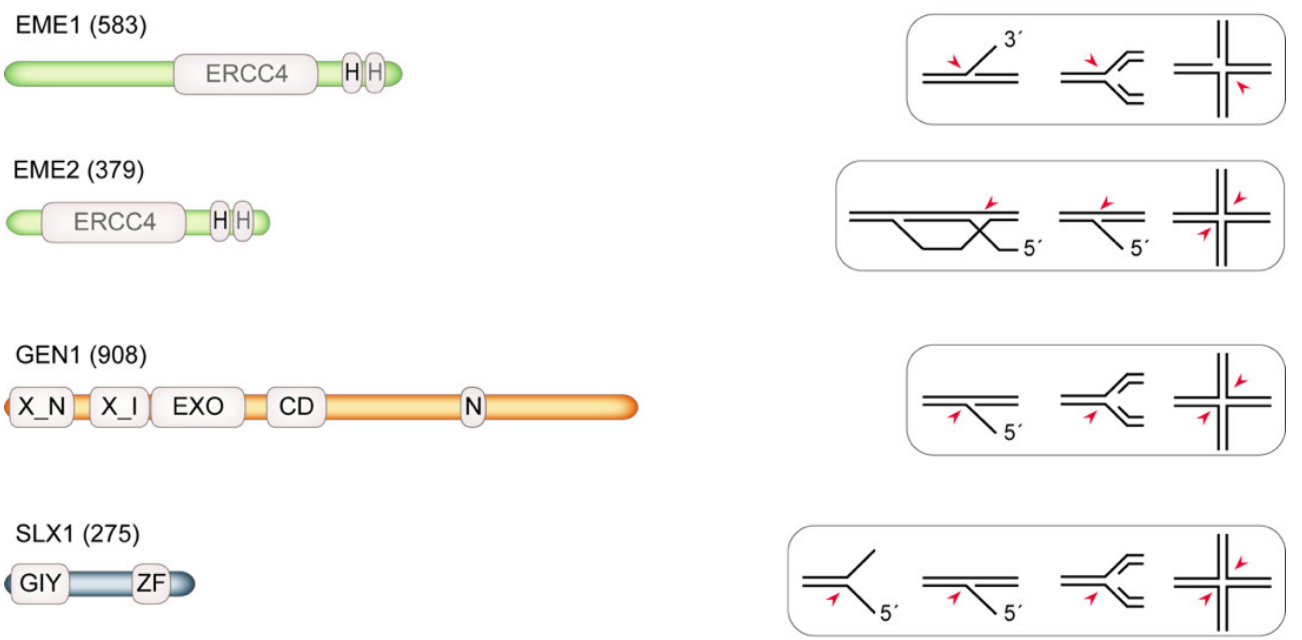

SLX4 (1834)

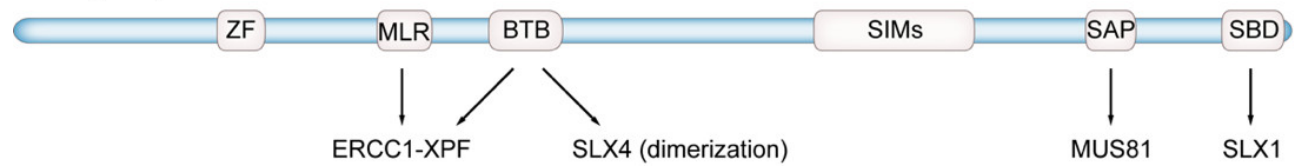

Figure 1. Human structure-specific endonuclease (SSE) domain structures and DNA substrate specificities. MUS81 and its alternative binding partners EME1 and EME2 (length in amino acids is indicated) contain ERCC4 endonuclease domain and helix-hairpin-helix $(\mathrm{H})$ motifs (gray font denotes degenerate motifs). While MUS81-EME1 exhibits activity on 3'-flaps, replication forks (RFs) and nicked Holliday junctions (HJs) (red arrows), MUS81-EME2 additionally cleaves D-loop strand-invasion structures and $5^{\prime}$-flaps as well as being more active on intact HJs. As part of a SLX-MUS complex (see text), MUS81-EME1 effectively resolves HJs by symmetric cleavage after pre-nicking mediated by the SLX1-SLX4 nuclease. GEN1 contains N-terminal and internal XPG nuclease motifs (X_N and X_I), followed by a $5^{\prime}-3^{\prime}$ exonuclease domain (EXO) and a chromodomain (CD) that promotes substrate recognition [71]; $\mathrm{N}$ denotes a nuclear export signal. GEN1 cuts $5^{\prime}$-flaps, RFs and HJs. SLX1 is a GIY-YIG nuclease with a zinc-finger (ZF) at the C-terminus. Associated with SLX4 via a C-terminal SLX1-binding domain (SBD), SLX1 cleaves splayed arm, 5'-flap, RF and HJ substrates. SLX4 contains a ZF domain (two copies of ubiquitin-binding UBZ4), multiple SUMO-interacting motifs (SIMs) [72] and scaffolds a tri-nuclease complex that is known as SMX containing SLX1, MUS81-EME1 (bound at its SAP domain) and ERCC1-XPF (bound via MLR, BTB). Figure is modified from [5]. 


\subsection{MUS81}

MUS81 was identified in a screen for genes that are essential in the absence of BLM homologue SGS1 in budding yeast [73]. The lethality of sgs1 mus81 double mutant cells was suppressed by inactivating HR [74], which indicates that an accumulation of recombination intermediates arising in the absence of Sgs1-mediated HJ dissolution imposes an essential requirement for Mus81 [73]. Mus81 is a member of the XPF structure-specific endonuclease family and possesses the typical ERCC4 nuclease domain and a pair of terminal helix-hairpin-helix motifs that mediate heterodimer formation with constitutive, non-catalytic subunits [75,76]. These are Mms4 in budding yeast, Eme1 in fission yeast and EME1 or EME2 in vertebrates [77-82]. Mus81 complexes from yeast and human were shown to cleave multiple branched DNA substrates, such as DNA 3'-flaps, RFs and HJs. Curiously, recombinant Mus81 consistently showed a clear preference for nicked HJ substrates while cleaving canonical, intact HJs inefficiently $[77,83,84]$. This is different for MUS81 in complex with EME2, an alternative heterodimeric partner found in vertebrates. The human MUS81-EME2 complex is catalytically more effective than MUS81-EME1 in biochemical assays and can, as a stand-alone nuclease, cleave a wider variety of substrates, including intact HJs and displacements loops (D-loops) generated by HR-mediated strand invasion $[85,86]$ (Figure 1). MUS81-EME2 appears to play a particularly prominent role in the cleavage of RFs [87], which is discussed in more detail below.

Across organisms, Mus81/MUS81 activity is tightly regulated in a cell cycle-dependent manner. In yeast, the catalytic activity of Mus81 is boosted by CDK-dependent hyperphosphorylation of Mms4 (or Eme1 in fission yeast) when the cells approach the G2/M phase of the cell cycle $[88,89]$. Consistently, 3'-flaps, RFs and nicked HJs were efficiently cleaved by the purified Mus81-Mms4 complex from G2/M cells but not from G1 or S phase-arrested cells [90]. Mms4 hyper-phosphorylation is a multi-step process. First, Cdc5 and Dbf4-dependent kinase (DDK) associate with the scaffold protein Rtt107, which mediates the initial Mms4 phosphorylation together with CDK (Cdc28). This favors the association of Rtt107 and its binding partners with Mms4, providing a positive feedback loop that leads to the hyperphosphorylation of Mms4 when Cdc5 expression peaks towards the end of genome replication [90-92]. The cooperation of three kinases acts like a molecular switch, preventing Mus81 activity early in the cell cycle [93] but ensuring robust activation in G2/M. Following mitosis, Mms4 phosphorylation is no longer observed [90] but it is currently unclear whether this is achieved through protein turnover and/or active dephosphorylation. HJ cleavage by Mus81-Mms4 is further modulated by the sumo-like domain protein Esc2 [94] and the proliferating cell nuclear antigen (PCNA) sliding clamp and the clamp loader replication factor $\mathrm{C}$ (RFC), which might play a role in recruiting Mus81 to perturbed replication intermediates [95]. Similarly to yeast, the ability of human MUS81 to cleave HJ substrates correlates with the PLK1 and CDK1-dependent phosphorylation of EME1 $[88,96]$. However, human MUS81 effectively cleaves RF-type substrates at all stages of the cell cycle, indicating that it is not the nuclease activity per se that is cell-cycle regulated [97]. Instead, MUS81-EME1 associates with SLX1-SLX4 and XPF-ERCC1 to form a cell cycle-dependent tri-nuclease complex with HJ resolution activity [96,98-101] (see Section 5.3 below). The interaction with SLX1-SLX4 seems critical for the recruitment of MUS81 to chromatin during mitosis [97,102].

\subsection{Slx1-Slx4/SLX1-SLX4}

Slx1/SLX1 belongs to the UvrC family of endonucleases with an N-terminal GIY-YIG nuclease domain and a C-terminal zinc-finger domain. Associated with the much larger, multi-domain Slx4/SLX4 protein, Slx1/Slx1 cleaves a variety of DNA substrates, including $5^{\prime}$ flaps, RF analogs and HJs $[98-100,103,104]$ (Figure 1). SLX1 and SLX4 were uncovered by the same screen for synthetic lethality with sgs1 that identified MUS81-MMS4 in budding yeast [73]. In contrast to mus81 sgs1 cells, the lethality of $s l x 1$ sgs1 or $s l x 4$ sgs 1 cells was not suppressed in the absence of HR. It has been proposed that Sgs1 and Slx1-Slx4 cooperate in maintaining the rDNA array in yeast, which might potentially happen by processing stalled RFs to initiate recombinational repair $[103,105,106]$. 
In human, SLX1-SLX4 interacts with MUS81-EME1 and XPF-ERCC1 to form the abovementioned tri-nuclease complex that is known as SMX, which functions as a highly effective HJ resolvase [96,98-101]. Consistently, epistasis analyses place SLX1, SLX4 and MUS81 in the same pathway of $\mathrm{HJ}$ resolution, suppressing sister-chromatid entanglements and mitotic chromosome non-disjunction [107]. However, the expression of SLX4 mutants that are unable to bind MUS81 or SLX1 partially rescues mitotic defects in SLX4-deficient cells [108], pointing to potential additional SLX1 and MUS81-independent roles of SLX4 in the processing of branched DNA intermediates [109]. In human, SLX4 is one of the genes mutated in Fanconi anemia (and is therefore also known as FANCP), a rare genetic disorder characterized by defective repair of replication-blocking inter-strand DNA crosslinks, genome instability, bone marrow failure and a high susceptibility to cancer $[110,111]$.

The crystal structure analyses of Candida glabrata Slx1 and the C-terminal region of Slx4 suggest that the formation of inactive Slx1 homodimers provides a means of regulating Slx1-Slx4 complex formation and activity [112]. However, as alluded to above, the control over MUS81 and SLX1-SLX4-dependent HJ resolution has to be considered in the context of cell cycle-dependent SMX complex formation.

\subsection{The SMX Tri-Nuclease Complex}

At its core, the SMX complex has the composite SLX-MUS resolvase that mediates HJ resolution by a SLX1-nick/MUS81-EME1-counternick mechanism [96,100,113]. Co-crystal structures of MUS81-EME1 with DNA have revealed a binding pocket for the $5^{\prime}$-end present at a nick that appears to provide substrate selectivity and enzyme positioning for $\mathrm{HJ}$ incision at a point precisely opposite a pre-existing nick [114]. Thus, HJ nicking by SLX1 creates a reference point for HJ resolution by MUS81-EME1, while SLX4 ensures coordinated cleavage by tethering MUS81 and SLX1. These observations provide an explanation for the increased efficiency of four-way DNA junction cleavage upon the association of MUS81-EME1 with SLX1-SLX4 [96,97]. The remaining subunit of SMX, the XPF-ERCC1 heterodimer, stimulates the HJ resolvase activity of SLX-MUS in a manner that is independent of its own nuclease activity [101].

SMX complex formation is governed by the activity of cell-cycle kinases. MUS81 exhibits the highest level of $\mathrm{HJ}$ resolution activity when purified from cells arrested in prometaphase by nocodazole at the time when MUS81-EME1 is found to be physically associated with SLX1-SLX4 $[88,96]$. This protein-protein interaction is dependent on CDK1 and, to a lesser extent, PLK1 activity, and is thus restricted to late cell-cycle phases [96]. CK2-dependent phosphorylation of MUS81 and CDK1-dependent phosphorylation of the SLX4 C-terminal SAP domain have been shown to promote MUS81-SLX4 interactions [72,97,115]. SLX1-SLX4 depletion or ablation of the MUS81 binding domain of SLX4 results in diminished HJ resolution activity of affinity-purified MUS81 or SLX1-SLX4, respectively $[96,100]$. These findings provide strong evidence that DNA four-way junction cleavage occurs in the context of the SLX-MUS complex in vivo.

In budding yeast, Mus81-Mms4, Slx1-Slx4 and Rad1-Rad10 (the homologue of XPF-ERCC1) have been shown to localize to the same sub-nuclear foci in response to RS and DNA damage [116]. Their localization was not interdependent and did not require the scaffolding function of Slx4, which is consistent with earlier experiments that failed to detect assemblies of a MUS-SLX resolvase in yeast after DNA damage treatment [117]. SSE colocalization occurred in the G1 and S phases and proteins became dispersed upon Mus81-Mms4 activation by hyperphosphorylation in G2/M [116]. These findings suggest that yeast SSEs may be recruited by a common stress-induced signal rather than physical interactions within an SMX complex. However, in a striking parallel to the human system, Mus81-Mms4 has been shown to join the abovementioned complex containing Slx4-Rtt107-Dpb11 as cells enter mitosis $[118,119]$. Rather than direct binding of Slx4, Mus81-Mms4 recruitment is dependent on a physical interaction between Mms4 and Dpb11, which is mediated by Cdc5 [119]. In contrast to the human system, the Slx4-Dpb11-Mus81-Mms4 complex facilitated the timely resolution of 
branched DNA intermediates in a Slx1-independent manner and it remains to be determined whether a SLX-MUS-type resolvase is formed in yeast $[119,120]$.

\subsection{Yen1/GEN1}

Yen1 and GEN1 were identified by a two-pronged approach that involved screening the affinity-purified protein complexes from yeast for $\mathrm{HJ}$ resolution activity and analyzing HeLa protein fractions with high specific HJ resolution activity by mass spectrometry [121,122]. Yen1/GEN1 are members of the Rad2/XPG nuclease family and possess a bi-partite N-terminal/internal XPG nuclease domain and helix-hairpin-helix domain [123]. While the enzyme is conserved from yeast to humans, it is conspicuously absent in fission yeast, where the heterologous expression of GEN1 can partially substitute for Mus81-Eme1 [71,124-129]. Like all other members of the XPG family, Yen1/GEN1 cuts $5^{\prime}$-flap structures but is the only family member that can cleave fully double-stranded three and four-way DNA junctions [121,130] (Figure 1). GEN1 is monomeric in solution and dimerizes on HJs, after which it triggers resolution by dual incision [71,129,131-134].

In contrast to Mus81-Mms4, Yen1 is inhibited by CDK. Phosphorylated Yen1 resides in the cytoplasm and accumulates in the nucleus after anaphase entry triggers its dephosphorylation by Cdc14. This activates a nuclear import signal and increases the DNA-binding activity of Yen1 [88,135-137]. In addition to the regulation by cell cycle-dependent phosphorylation, Yen1 is sumoylated in response to DNA damage. Yen1 sumoylation leads to Slx5-Slx8-dependent ubiquitination and release from DNA. It has been proposed that increased Yen1 turnover mediated by sumoylation limits the mutagenic effects of Yen1 actions on DNA [138].

Nuclear envelope breakdown during mitosis in mammalian cells necessitates a different form of regulation of GEN1 compared to Yen1 in yeast. Strikingly, GEN1 regulation also follows a strategy of cytoplasmic sequestration. A nuclear export signal within GEN1 mediates cytosolic localization throughout interphase (Figure 1), while GEN1 automatically gains access to mitotic chromosomes in prometaphase [139]. GEN1 is phosphorylated in M phase in a similar way to Yen1 although this does not appear to modulate its HJ resolvase activity and the functional consequences of this post-translational modification remain to be determined [139].

\section{Holliday Junction Resolution by Structure-Specific Endonucleases Facilitates Chromosome Segregation}

The canonical function of $\mathrm{HJ}$ resolvases is the removal of late HR intermediates. As mentioned above, RF recovery and post-replicative DNA repair pathways rely on HR [140,141] (Figure 2). After this, HJ processing severs any remaining DNA links that may compromise chromosome segregation. The loss of MUS-SLX and Yen1/Gen1-dependent branched-DNA processing sensitizes cells to a variety of agents that impair replication progression by inducing DNA damage and RS. Mus81-defective yeast cells exhibit RS sensitivity, spontaneous chromosome loss, persistence of anaphase-bridge structures and segregation failure and these phenotypes are exacerbated in the absence of Yen1 [119,142-147]. Many of the defects can be ameliorated by eliminating HR, which indicates an involvement of unresolved recombination intermediates $[136,143,144]$. In human cells, the perturbation of the MUS-SLX and GEN1 pathways leads to elevated levels of mitotic chromosome bridges and UFBs, chromosome segregation defects, micronuclei and transmission of DNA damage to daughter cells $[96,107,108,148,149]$. A recently described UFB sub-type, formed in a manner dependent on HR proteins RAD51 and BRCA2 (termed HR-UFBs), is strongly elevated upon the disruption of MUS81 and GEN1 under RS conditions. This provides evidence that SSE-dependent processing of HR intermediates arising at perturbed RFs is required to ensure that chromosomes are disentangled in time for segregation [150].

Being governed by the regulatory mechanisms described above, which direct the actions of Yen1/GEN1 and Mus81/MUS-SLX towards mitotic chromosomes, HJ resolution occurs late in the cell cycle. Disrupting cell-cycle control over HJ resolution leads to increased crossover formation 
and loss of heterozygosity from yeast to humans $[93,135,139,151]$. This can be explained by the fact that HJ cleavage by SSEs produces crossover and non-crossover HR outcomes in equal measure. In contrast, $\mathrm{HJ}$ dissolution along the Sgs1/BLM-dependent decatenation pathways always leads to non-crossovers [152]. Thus, delaying the action of SSEs until after bulk DNA synthesis is completed provides a window of opportunity to dissolve-rather than resolve-HR intermediates, preventing sister chromatid exchange, chromosomal translocations (in case of non-allelic recombination) and loss of heterozygosity.

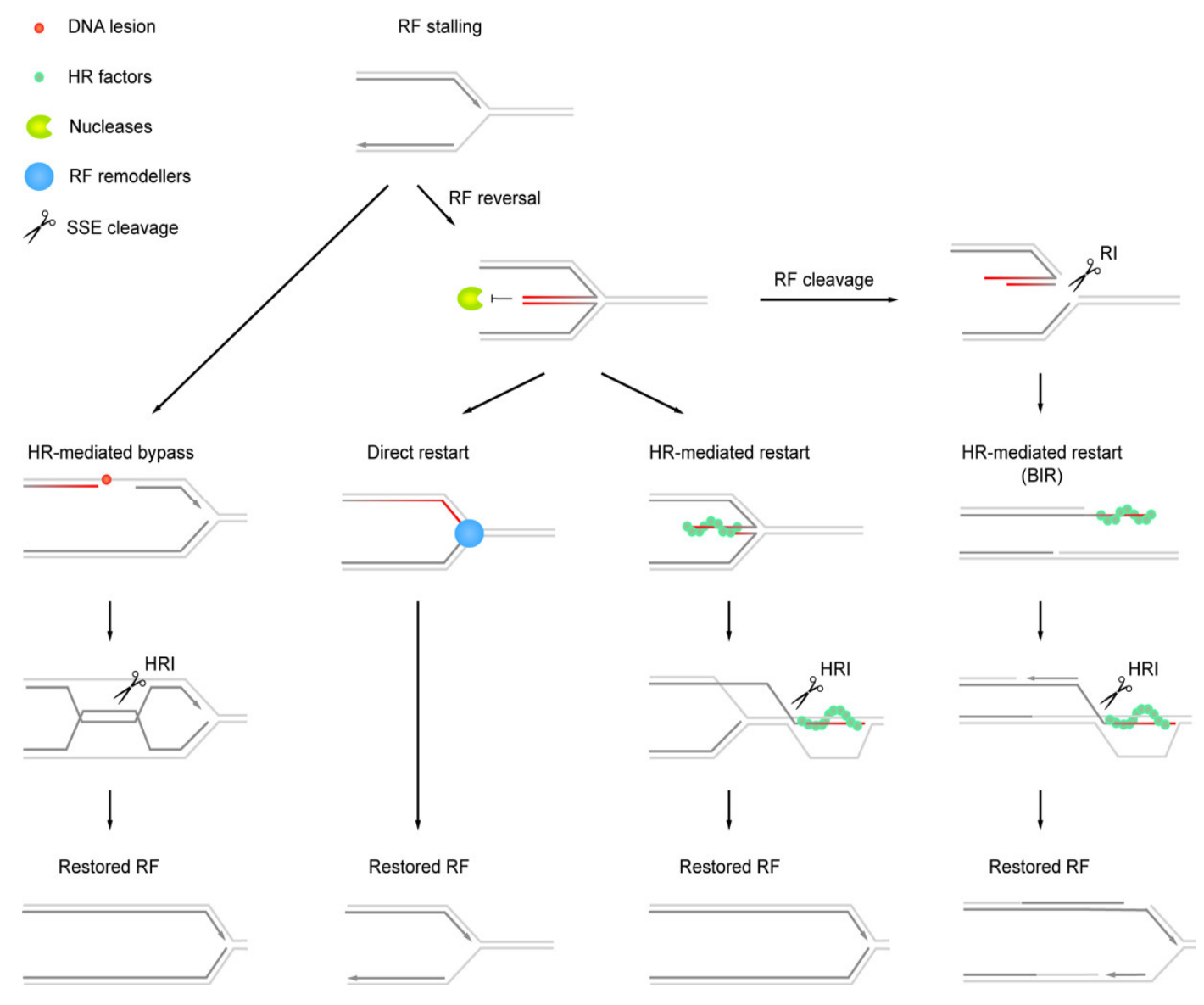

Figure 2. Multiple roles of SSEs in RF recovery. SSEs target replication (RI) and HR (HRI) intermediates to facilitate replication restart and completion. At DNA lesions, RF arrest may be overcome by HR-mediated bypass. Re-initiation of DNA synthesis downstream of lesions leaves daughter-strand gaps that are subsequently filled in by template switching. The ensuing HRIs may be removed by Sgs1/BLM-dependent dissolution (not depicted on figure) or cleavage by SSEs. RF reversal by disengagement of the leading and lagging strands at stalled forks followed by nascent-strand annealing generates HJ-like DNA four-way RIs. These intermediates are shielded from degradation, which facilitates passive rescue by converging RFs. If reversed RFs are not permanently inactivated, such as by replisome loss, remodeling for direct restart that is mediated by DNA helicases/translocases may be possible. Alternatively, functional RFs are restored by HR-mediated restart through invasion of the upstream template and associated HRIs are removed by SSEs. Persistent RIs have emerged as important non-HRI targets of SSEs. The cleavage of RF structures produces single-ended DNA double-strand breaks, triggering break-induced replication (BIR). Invasion of the unbroken sister chromatid generates a D-loop and subsequently a new processive RF. HRIs formed along the BIR pathway are once again resolved by SSEs.

Unscheduled nuclear entry of Yen1 during $S$ phase has been shown to result in replication stress sensitivity $[135,151]$. Thus, the haphazard processing of DNA replication and repair intermediates is 
another risk that is associated with SSE activity during S phase. Perhaps the most striking examples of chromosome breakage and genome instability upon SSE dysregulation are observed when CDK1 is prematurely activated by the inhibition of either the G2 checkpoint kinase WEE1 or checkpoint protein CHK1 [153-158]. Under these conditions, aberrant SLX-MUS complexes formed in the S phase can trigger a massive cleavage of replicating DNA, which results in a chromosome pulverization phenotype [97]. Restricting HJ resolution to mitosis thus serves a dual purpose of protecting ongoing replication, while ensuring that chromosomal DNA links can be fully removed when segregation is imminent.

\section{Structure-Specific Endonucleases Cleave DNA Replication Intermediates to Promote Cell Viability}

Despite the dangers associated with access of SSEs to replicating chromosomes, evidence has been solidifying in recent years that SSEs target persistent replication intermediates to promote the completion of genome replication. In mouse cells, protracted treatment with DNA replication inhibitors was shown to provoke MUS81-dependent chromosomal breaks that were correlated with replication restart $[159,160]$. These observations are compatible with the conversion of arrested RFs into transient DNA double-strand breaks, which subsequently serve as substrates for HR-dependent replication restart along the break-induced replication (BIR) pathway [161] (Figure 2). BIR can overcome replication breakdown by rebuilding RFs without the need for fresh origin firing, thus providing an opportunity to complete genome replication at difficult-to-replicate and damaged chromosomal sites. Consistently, MUS81 can promote chromosome breakage, replication restart and viability in human cells suffering various types of endogenous and exogenous replication stress [40,148,149,162-168]. MUS81-dependent DNA breaks result from alternative complexes containing MUS81-EME1 or MUS81-EME2, with the latter being particularly relevant to RF processing in S-phase cells $[87,169]$. Interestingly, in contrast to MUS81-EME1, MUS81-EME2 has the ability to process D-loop structures, such as those generated by strand invasion during BIR [86]. This raises the possibility that the actions of MUS81-EME2 may be involved in initiating replication restart by BIR and subsequently in limiting the extent of BIR-associated DNA synthesis. BIR-associated replication is error-prone and at least in yeast, Mus81-Mms4 has been shown to limit the mutagenic effects of BIR [170].

Replication stress is a hallmark of cancer, driving genome instability during tumorigenesis [171]. The involvement of MUS81-EME1 and MUS81-EME2 in RF processing and restart highlights the potential of these and other enzymes involved in RF recovery as possible anti-cancer targets.

\section{Structure-Specific Endonuclease-Mediated Cleavage of DNA Replication Intermediates Initiates DNA Repair Synthesis in Mitosis}

As mentioned above, underreplication gives rise to UFBs and chromosome segregation defects (Figure 3). UFBs, which remain undetected by conventional DNA dyes, are identified by their association with a characteristic set of proteins, including Polo-like kinase 1-interacting checkpoint helicase (PICH; also known as ERCC6-like protein) and BLM [58,59]. In contrast to HR-UFBs [172,173], UFBs believed to result from unreplicated segments of DNA, which are often found associated with CFSs, are flanked by foci of Fanconi anemia protein FANCD2 [60,174]. In early mitosis, a PLK1-dependent SMX complex containing the MUS81-EME1 and XPF-ERCC1 nucleases localizes with FANCD2 on chromosomes, suppresses UFBs and promotes fragile-site expression that is associated with new DNA synthesis $[148,149,175]$. Based on these observations, a pathway of mitotic DNA synthesis (MiDAS) has been proposed, which resolves persistent replication intermediates in an SSE-dependent manner and initiates repair DNA synthesis when the chromosomes condense in preparation for segregation [175]. MiDAS may be viewed as a last-ditch attempt to complete chromosome replication and a catchall for unreplicated DNA that may escape checkpoint surveillance and pose a serious threat to sister chromatid disjunction and chromosome integrity. In light of this, CFS-associated gaps on mitotic chromosomes are a manifestation of ongoing MiDAS, which 
locally precludes chromosomal condensation, rather than unrepaired DNA damage $[148,149,175]$ (Figure 3). MiDAS requires HR mediator RAD52 but is inhibited by the strand-exchange recombinase RAD51 [176,177]. RAD52 can catalyze strand annealing and supports BIR at regions bearing small homologies [178-180], which suggests that MiDAS represents microhomology-mediated BIR initiated at SSE-generated DNA breaks at arrested RFs [181]. Consistently, MiDAS requires the non-catalytic POLD3 subunit of polymerase $\delta$ and involves a conservative mode of DNA replication in a similar way to BIR $[175,177]$. However, a feature that clearly distinguishes MiDAS from other instances of RF collapse and BIR-dependent replication restart is its apparent dependence on chromosome compaction, making MiDAS a truly mitotic phenomenon. The inhibition of chromosome condensation or stabilization of cohesion on sister-chromatid arms prevented the recruitment of MUS81 and precluded MiDAS [175]. It has been suggested that DNA compaction may expose underreplicated segments of DNA, conceivably facilitating their processing by SSEs [175]. MiDAS is strongly elevated under RS conditions and particularly prevalent in aneuploid cell lines, which makes the pathway an attractive potential target for cancer therapy $[175,182]$.

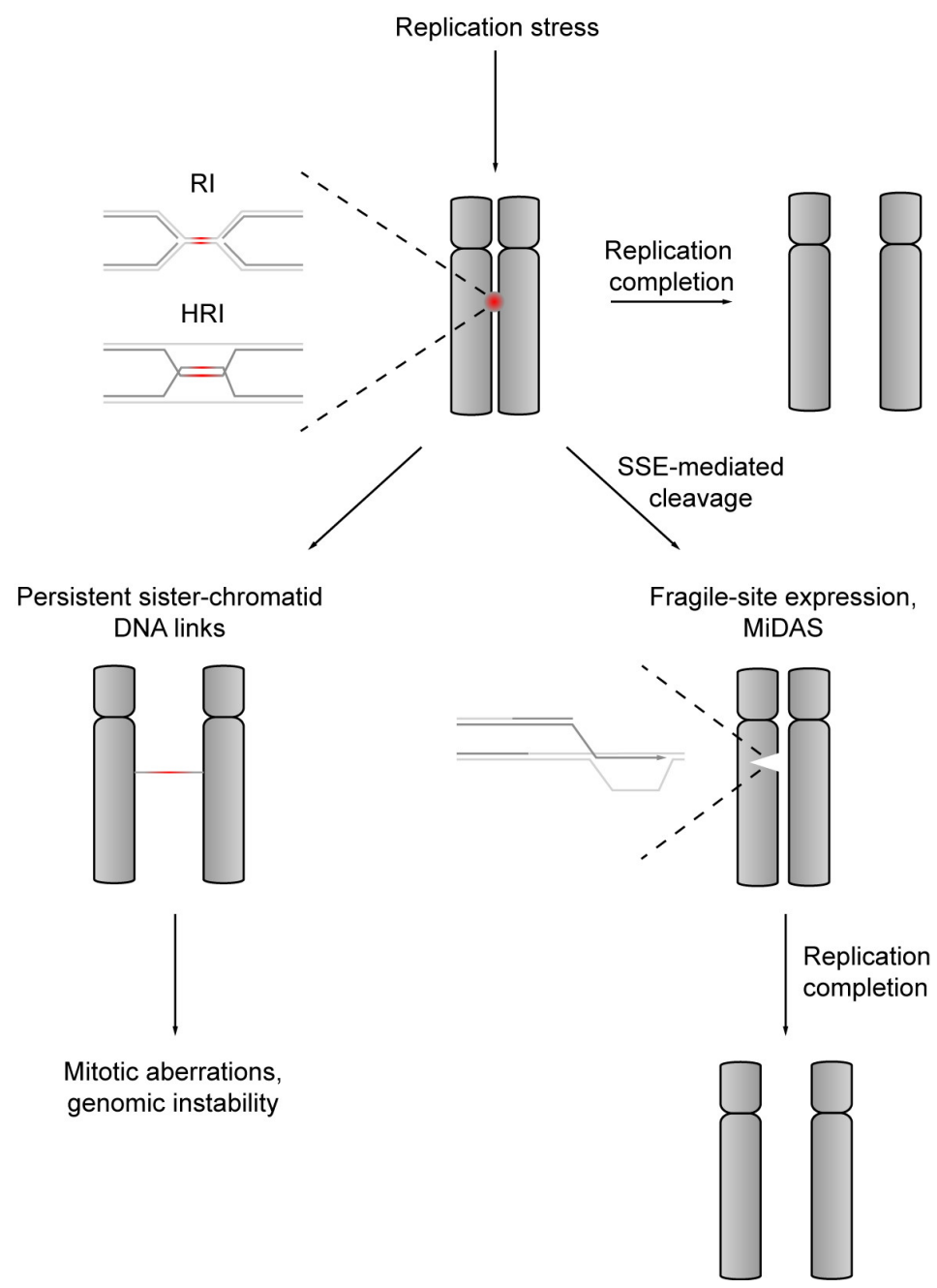

Figure 3. SSEs promote sister chromatid disjunction and replication completion. RS leads to an accumulation of unresolved replication (RI) and HR (HRI) intermediates linking nascent sister chromatids. If replication is not completed in S phase and not all RIs and HRIs are removed, SSEs resolve persistent intermediates in mitosis. RI cleavage initiates late DNA repair synthesis along the mitotic DNA synthesis (MiDAS) pathways, which promotes replication completion in mitotic cells and safeguards sister chromatid disjunction. Failure to resolve RI and HRI sister chromatid DNA links leads to BLM and PICH-bound UFBs, mitotic DNA damage and segregation failure. 
In yeast, Yen1 has been implicated in the mitotic resolution of underreplicated DNA. Yen1-mutant cells exhibit hypersensitivity to RS upon inactivation of the helicase domain within the Dna2 nuclease-helicase [183-185]. This synthetic-sick relationship persisted in the absence of Rad52, indicating that Yen1 targets in Dna2-mutant cells arise independently of HR [185]. In human cells, DNA2 has been shown to promote DNA replication and facilitate the restart of stalled RFs [186-189]. Consistently, replication intermediates accumulate in Dna2 helicase-defective yeast cells and preclude chromosome segregation unless they are resolved by Yen1 [185]. Due to the fact that Yen1 activity is restricted to mitosis, Dna2-mutant cells are prone to terminal G2/M DNA damage checkpoint arrest when exposed to RS [185]. Conversely, $\mathrm{Yen}^{\mathrm{ON}}$, which is a constitutively nuclear and active Yen1 mutant [135], supports the growth of otherwise inviable dna2 $\Delta$ cells [190]. It remains to be determined whether Yen1 cleavage of persistent replication structures results in mitotic DNA synthesis or transmission of DNA breaks to daughter cells. Either way, DNA cleavage of replication intermediates that have escaped Dna2 activity prevents mitotic catastrophe and restores near wild-type levels of viability to Dna2 helicase-mutant cells [185]. In human, the mutations in DNA2 are associated with Seckel syndrome, one of the microcephalic primordial dwarfism disorders that have been linked to defective RF recovery [191,192]. In cancer, on the other hand, DNA2 is frequently overexpressed, potentially reflecting an adaptation to endogenous RS and elevated levels of RF stalling [193,194]. If a two-tiered DNA2-GEN1 mechanism for the processing of persistent replication intermediates is conserved in humans, inhibiting these enzymes may provide a means to kill cancer cells by stress overload.

\section{Structure-Specific Endonuclease Targets Arising at Stalled Replication Forks}

The versatile DNA debranching activities of Mus81-Mms4/MUS81-EME1, MUS81-EME2, Slx1-Slx4/SLX1-SLX4 and Yen1/GEN1 at three-way and four-way DNA junctions suggest that these SSEs may be capable of cleaving a wide variety of failing replication intermediates in vivo. Direct observations of DNA topology by electron microscopy have revealed reversed RF intermediates that are structurally equivalent to HJs [195] (Figure 2). These intermediates are ubiquitous in human cells but accumulate under RS conditions when MUS81 is absent, indicating that SSEs target the remodeled four-way replication structures or arrested RFs that give rise to them $[40,196,197]$.

RF remodeling involving DNA strand separation and strand annealing can be catalyzed by a number of factors, including the DNA helicases and translocases RAD54, HTFL, FBH1, FANCM, SMARCAL1, ZRANB3, BLM and WRN [198]. RF reversal appears to protect from breakage, suggesting that changes in the architecture of forks that were originally perceived as pathologic and detrimental constitute a controlled response to RF stalling [40,165,195,199-201]. The regressed arm at reversed RFs has an exposed DNA end and is susceptible to degradation. In human cells, the tumor suppressor BRCA2 promotes the formation of protective RAD51 filaments on reversed RFs, acting in an HR-independent role to block MRE11-mediated nucleolytic degradation and RF demise [196,202-207]. Preserving reversed RFs may facilitate passive rescue by fork convergence upon the arrival of a neighboring RF. Alternatively, reversed RFs are converted back to three-way processive forks by the controlled resection of the regressed arm and/or branch migration $[43,188,208]$ (see "direct restart" in Figure 2). Active three-way/four-way structure interconversions mediated by bacterial and viral DNA repair helicases in reconstituted in vitro systems suggest that RF recovery by fork remodeling is a ubiquitous mechanism $[209,210]$. If direct restart fails, RFs can be restored by cleavage-free HR-dependent mechanisms, involving the invasion of the upstream parental duplex by the regressed arm (see "HR-mediated restart" in Figure 2). However, persistent replication intermediates will eventually become susceptible to SSE cleavage late in the cell cycle, when the HJ resolvases are activated and targeted to chromatin as described above (see "RF cleavage" in Figure 2). This ensures sister chromatid disjunction when chromosome segregation approaches although MiDAS and/or DNA damage repair in daughter cells may subsequently be required for replication completion (Figure 3). It is tempting to speculate that reversed fork structures that are distinct from conventional three-way 
RFs may attract SSEs in vivo but it is currently unclear whether proper nucleolytic processing is dependent upon prior RF remodeling. It will also be interesting to learn how MUS81-EME2 can be targeted to inactivated RFs in S phase while sparing similar structures that are actively engaged in DNA synthesis. The association of the replisome and other replication/repair factors crowding RFs certainly plays a role in the structural conformation and accessibility of RFs for SSEs.

\section{Conclusions}

In the last few years, there has been considerable progress in our understanding of the function and regulation of SSEs in the resolution of underreplication and sister chromatid non-disjunction. The general picture that has emerged is that SSEs are subject to multiple layers of regulation that largely restrict their activities to mitosis. This serves to protect ongoing replication in $S$ phase and ensures that the persistent chromosomal DNA links are removed in time for chromosome segregation. Incomplete replication may escape checkpoint surveillance but SSEs are mobilized at every mitosis and are ready to avert anaphase-bridge formation and mitotic catastrophe. Perhaps one of the most striking discoveries is the SSE-mediated initiation of DNA synthesis along the MiDAS pathway, identifying a surprisingly late-acting mechanism of replication completion in mitosis. MiDAS provides an appealing solution for maintaining genome stability despite the inevitability of local underreplication during genome replication. The advances that are being made in our detailed understanding of the mechanisms related to RS and chromosomal underreplication will no doubt feed into strategies exploiting cancer-associated RS for new anti-cancer therapeutic approaches.

Author Contributions: Both authors contributed to defining the form and content of this review article and wrote the manuscript.

Funding: This research received no external funding.

Acknowledgments: Our work on SSEs and replication stress was supported by the Friedrich Miescher Institute for Biomedical Research in Basel and the Novartis Research Foundation. We thank Kok-Lung Chan for helpful discussions.

Conflicts of Interest: The authors declare no conflict of interest.

\section{References}

1. Holliday, R. A mechanism for gene conversion in fungi. Genet. Res. 1964, 5, 282-304. [CrossRef]

2. Liu, Y.; West, S.C. Happy Hollidays: 40th anniversary of the Holliday junction. Nat. Rev. Mol. Cell Biol. 2004, 5, 937-944. [CrossRef]

3. Wu, L.; Hickson, I.D. The Bloom's syndrome helicase suppresses crossing over during homologous recombination. Nature 2003, 426, 870-874. [CrossRef] [PubMed]

4. Wyatt, H.D.M.; West, S.C. Holliday junction resolvases. Cold Spring Harb. Perspect. Biol. 2014, 6, a023192. [CrossRef] [PubMed]

5. Rass, U. Resolving branched DNA intermediates with structure-specific nucleases during replication in eukaryotes. Chromosoma 2013, 122, 499-515. [CrossRef]

6. Rivera-Mulia, J.C.; Gilbert, D.M. Replicating large genomes: Divide and conquer. Mol. Cell 2016, 62, 756-765. [CrossRef]

7. Blow, J.J.; Ge, X.Q.; Jackson, D.A. How dormant origins promote complete genome replication. Trends Biochem. Sci. 2011, 36, 405-414. [CrossRef] [PubMed]

8. Fragkos, M.; Ganier, O.; Coulombe, P.; Méchali, M. DNA replication origin activation in space and time. Nat. Rev. Mol. Cell Biol. 2015, 16, 360-374. [CrossRef]

9. Newman, T.J.; Mamun, M.A.; Nieduszynski, C.A.; Blow, J.J. Replisome stall events have shaped the distribution of replication origins in the genomes of yeasts. Nucleic Acids Res. 2013, 41, 9705-9718. [CrossRef]

10. Kawabata, T.; Luebben, S.W.; Yamaguchi, S.; Ilves, I.; Matise, I.; Buske, T.; Botchan, M.R.; Shima, N. Stalled fork rescue via dormant replication origins in unchallenged $S$ phase promotes proper chromosome segregation and tumor suppression. Mol. Cell 2011, 41, 543-553. [CrossRef] 
11. Bellelli, R.; Borel, V.; Logan, C.; Svendsen, J.; Cox, D.E.; Nye, E.; Metcalfe, K.; O'Connell, S.M.; Stamp, G.; Flynn, H.R.; et al. Pole instability drives replication stress, abnormal development, and tumorigenesis. Mol. Cell 2018, 70, 707-721. [CrossRef] [PubMed]

12. Ge, X.Q.; Jackson, D.A.; Blow, J.J. Dormant origins licensed by excess Mcm2-7 are required for human cells to survive replicative stress. Genes Dev. 2007, 21, 3331-3341. [CrossRef]

13. Woodward, A.M.; Göhler, T.; Luciani, M.G.; Oehlmann, M.; Ge, X.; Gartner, A.; Jackson, D.A.; Blow, J.J. Excess Mcm2-7 license dormant origins of replication that can be used under conditions of replicative stress. J. Cell Biol. 2006, 173, 673-683. [CrossRef] [PubMed]

14. Ibarra, A.; Schwob, E.; Mendez, J. Excess MCM proteins protect human cells from replicative stress by licensing backup origins of replication. Proc. Natl. Acad. Sci. USA 2008, 105, 8956-8961. [CrossRef] [PubMed]

15. Kunnev, D.; Rusiniak, M.E.; Kudla, A.; Freeland, A.; Cady, G.K.; Pruitt, S.C. DNA damage response and tumorigenesis in Mcm2-deficient mice. Oncogene 2010, 29, 3630-3638. [CrossRef] [PubMed]

16. Maya-Mendoza, A.; Petermann, E.; Gillespie, D.A.F.; Caldecott, K.W.; Jackson, D.A. Chk1 regulates the density of active replication origins during the vertebrate $S$ phase. EMBO J. 2007, 26, 2719-2731. [CrossRef]

17. Syljuåsen, R.G.; Sørensen, C.S.; Hansen, L.T.; Fugger, K.; Lundin, C.; Johansson, F.; Helleday, T.; Sehested, M.; Lukas, J.; Bartek, J. Inhibition of human Chk1 causes increased initiation of DNA replication, phosphorylation of ATR targets, and DNA breakage. Mol. Cell. Biol. 2005, 25, 3553-3562. [CrossRef]

18. Toledo, L.I.; Altmeyer, M.; Rask, M.-B.; Lukas, C.; Larsen, D.H.; Povlsen, L.K.; Bekker-Jensen, S.; Mailand, N.; Bartek, J.; Lukas, J. ATR prohibits replication catastrophe by preventing global exhaustion of RPA. Cell 2013, 155, 1088-1103. [CrossRef]

19. Christensen, P.U.; Bentley, N.J.; Martinho, R.G.; Nielsen, O.; Carr, A.M. Mik1 levels accumulate in S phase and may mediate an intrinsic link between $S$ phase and mitosis. Proc. Natl. Acad. Sci. USA 2000, 97, 2579-2584. [CrossRef] [PubMed]

20. Lemmens, B.; Hegarat, N.; Akopyan, K.; Sala-Gaston, J.; Bartek, J.; Hochegger, H.; Lindqvist, A. DNA replication determines timing of mitosis by restricting CDK1 and PLK1 activation. Mol. Cell 2018, 71, 117-128. [CrossRef]

21. Sugimoto, K.; Shimomura, T.; Hashimoto, K.; Araki, H.; Sugino, A.; Matsumoto, K. Rfc5, a small subunit of replication factor C complex, couples DNA replication and mitosis in budding yeast. Proc. Natl. Acad. Sci. USA 1996, 93, 7048-7052. [CrossRef]

22. Hofmann, J.F.; Beach, D. Cdt1 is an essential target of the Cdc10/Sct1 transcription factor: Requirement for DNA replication and inhibition of mitosis. EMBO J. 1994, 13, 425-434. [CrossRef] [PubMed]

23. Piatti, S.; Lengauer, C.; Nasmyth, K. Cdc6 is an unstable protein whose de novo synthesis in G1 is important for the onset of $\mathrm{S}$ phase and for preventing a "reductional" anaphase in the budding yeast Saccharomyces cerevisiae. EMBO J. 1995, 14, 3788-3799. [CrossRef]

24. Bastos de Oliveira, F.M.; Kim, D.; Cussiol, J.R.; Das, J.; Jeong, M.C.; Doerfler, L.; Schmidt, K.H.; Yu, H.; Smolka, M.B. Phosphoproteomics reveals distinct modes of Mec1/ATR signaling during DNA replication. Mol. Cell 2015, 57, 1124-1132. [CrossRef]

25. Eykelenboom, J.K.; Harte, E.C.; Canavan, L.; Pastor-Peidro, A.; Calvo-Asensio, I.; Llorens-Agost, M.; Lowndes, N.F. ATR activates the S-M checkpoint during unperturbed growth to ensure sufficient replication prior to mitotic onset. Cell Rep. 2013, 5, 1095-1107. [CrossRef]

26. Saldivar, J.C.; Hamperl, S.; Bocek, M.J.; Chung, M.; Bass, T.E.; Cisneros-Soberanis, F.; Samejima, K.; Xie, L.; Paulson, J.R.; Earnshaw, W.C.; et al. An intrinsic S/G2 checkpoint enforced by ATR. Science 2018, 361, 806-810. [CrossRef]

27. Iyer, D.R.; Rhind, N. The intra-S checkpoint responses to DNA damage. Genes 2017, 8, 74. [CrossRef] [PubMed]

28. Saldivar, J.C.; Cortez, D.; Cimprich, K.A. The essential kinase ATR: Ensuring faithful duplication of a challenging genome. Nat. Rev. Mol. Cell Biol. 2017, 18, 622-636. [CrossRef]

29. Cha, R.S.; Kleckner, N. ATR homolog Mec1 promotes fork progression, thus averting breaks in replication slow zones. Science 2002, 297, 602-606. [CrossRef]

30. Casper, A.M.; Nghiem, P.; Arlt, M.F.; Glover, T.W. ATR regulates fragile site stability. Cell 2002, 111, 779-789. [CrossRef] 
31. Barlow, J.H.; Faryabi, R.B.; Callén, E.; Wong, N.; Malhowski, A.; Chen, H.T.; Gutierrez-Cruz, G.; Sun, H.-W.; McKinnon, P.; Wright, G.; et al. Identification of early replicating fragile sites that contribute to genome instability. Cell 2013, 152, 620-632. [CrossRef]

32. Shastri, N.; Tsai, Y.-C.; Hile, S.; Jordan, D.; Powell, B.; Chen, J.; Maloney, D.; Dose, M.; Lo, Y.; Anastassiadis, T.; et al. Genome-wide identification of structure-forming repeats as principal sites of fork collapse upon ATR inhibition. Mol. Cell 2018, 72, 222-238. [CrossRef] [PubMed]

33. Tubbs, A.; Sridharan, S.; van Wietmarschen, N.; Maman, Y.; Callén, E.; Stanlie, A.; Wu, W.; Wu, X.; Day, A.; Wong, N.; et al. Dual roles of poly(dA:dT) tracts in replication initiation and fork collapse. Cell 2018, 174, 1127-1142. [CrossRef]

34. Tercero, J.A.; Longhese, M.P.; Diffley, J.F.X. A central role for DNA replication forks in checkpoint activation and response. Mol. Cell 2003, 11, 1323-1336. [CrossRef]

35. Tercero, J.A.; Diffley, J.F. Regulation of DNA replication fork progression through damaged DNA by the Mec1/Rad53 checkpoint. Nature 2001, 412, 553-557. [CrossRef] [PubMed]

36. Lopes, M.; Cotta-Ramusino, C.; Pellicioli, A.; Liberi, G.; Plevani, P.; Muzi-Falconi, M.; Newlon, C.S.; Foiani, M. The DNA replication checkpoint response stabilizes stalled replication forks. Nature 2001, 412, 557-561. [CrossRef]

37. Sogo, J.M.; Lopes, M.; Foiani, M. Fork reversal and ssDNA accumulation at stalled replication forks owing to checkpoint defects. Science 2002, 297, 599-602. [CrossRef]

38. Froget, B.; Blaisonneau, J.; Lambert, S.; Baldacci, G. Cleavage of stalled forks by fission yeast Mus81/Eme1 in absence of DNA replication checkpoint. Mol. Biol. Cell 2008, 19, 445-456. [CrossRef]

39. El-Shemerly, M.; Hess, D.; Pyakurel, A.K.; Moselhy, S.; Ferrari, S. ATR-dependent pathways control hEXO1 stability in response to stalled forks. Nucleic Acids Res. 2008, 36, 511-519. [CrossRef]

40. Neelsen, K.J.; Zanini, I.M.Y.; Herrador, R.; Lopes, M. Oncogenes induce genotoxic stress by mitotic processing of unusual replication intermediates. J. Cell Biol. 2013, 200, 699-708. [CrossRef] [PubMed]

41. Cotta-Ramusino, C.; Fachinetti, D.; Lucca, C.; Doksani, Y.; Lopes, M.; Sogo, J.; Foiani, M. Exo1 processes stalled replication forks and counteracts fork reversal in checkpoint-defective cells. Mol. Cell 2005, 17, 153-159. [CrossRef]

42. Segurado, M.; Diffley, J.F.X. Separate roles for the DNA damage checkpoint protein kinases in stabilizing DNA replication forks. Genes Dev. 2008, 22, 1816-1827. [CrossRef] [PubMed]

43. Couch, F.B.; Bansbach, C.E.; Driscoll, R.; Luzwick, J.W.; Glick, G.G.; Bétous, R.; Carroll, C.M.; Jung, S.Y.; Qin, J.; Cimprich, K.A.; et al. ATR phosphorylates SMARCAL1 to prevent replication fork collapse. Genes Dev. 2013, 27, 1610-1623. [CrossRef] [PubMed]

44. Seiler, J.A.; Conti, C.; Syed, A.; Aladjem, M.I.; Pommier, Y. The intra-S-phase checkpoint affects both DNA replication initiation and elongation: Single-cell and -DNA fiber analyses. Mol. Cell. Biol. 2007, 27, 5806-5818. [CrossRef]

45. Santocanale, C.; Diffley, J.F. A Mec1- and Rad53-dependent checkpoint controls late-firing origins of DNA replication. Nature 1998, 395, 615-618. [CrossRef] [PubMed]

46. Shirahige, K.; Hori, Y.; Shiraishi, K.; Yamashita, M.; Takahashi, K.; Obuse, C.; Tsurimoto, T.; Yoshikawa, H. Regulation of DNA-replication origins during cell-cycle progression. Nature 1998, 395, 618-621. [CrossRef]

47. Dimitrova, D.S.; Gilbert, D.M. Temporally coordinated assembly and disassembly of replication factories in the absence of DNA synthesis. Nat. Cell Biol. 2000, 2, 686-694. [CrossRef] [PubMed]

48. Yekezare, M.; Gómez-González, B.; Diffley, J.F.X. Controlling DNA replication origins in response to DNA damage-inhibit globally, activate locally. J. Cell. Sci. 2013, 126, 1297-1306. [CrossRef] [PubMed]

49. Lundgren, K.; Walworth, N.; Booher, R.; Dembski, M.; Kirschner, M.; Beach, D. mik1 and wee1 cooperate in the inhibitory tyrosine phosphorylation of cdc2. Cell 1991, 64, 1111-1122. [CrossRef]

50. Boddy, M.N.; Furnari, B.; Mondesert, O.; Russell, P. Replication checkpoint enforced by kinases Cds1 and Chk1. Science 1998, 280, 909-912. [CrossRef]

51. Zeng, Y.; Forbes, K.C.; Wu, Z.; Moreno, S.; Piwnica-Worms, H.; Enoch, T. Replication checkpoint requires phosphorylation of the phosphatase Cdc25 by Cds1 or Chk1. Nature 1998, 395, 507-510. [CrossRef] [PubMed]

52. Furnari, B.; Rhind, N.; Russell, P. Cdc25 mitotic inducer targeted by chk1 DNA damage checkpoint kinase. Science 1997, 277, 1495-1497. [CrossRef] 
53. Sanchez, Y.; Wong, C.; Thoma, R.S.; Richman, R.; Wu, Z.; Piwnica-Worms, H.; Elledge, S.J. Conservation of the Chk1 checkpoint pathway in mammals: linkage of DNA damage to Cdk regulation through Cdc25. Science 1997, 277, 1497-1501. [CrossRef]

54. Palou, G.; Palou, R.; Zeng, F.; Vashisht, A.A.; Wohlschlegel, J.A.; Quintana, D.G. Three different pathways prevent chromosome segregation in the presence of DNA damage or replication stress in budding yeast. PLoS Genet. 2015, 11, e1005468. [CrossRef] [PubMed]

55. Al Mamun, M.; Albergante, L.; Moreno, A.; Carrington, J.T.; Blow, J.J.; Newman, T.J. Inevitability and containment of replication errors for eukaryotic genome lengths spanning megabase to gigabase. Proc. Natl. Acad. Sci. USA 2016, 113, E5765-E5774. [CrossRef]

56. Moreno, A.; Carrington, J.T.; Albergante, L.; Al Mamun, M.; Haagensen, E.J.; Komseli, E.-S.; Gorgoulis, V.G.; Newman, T.J.; Blow, J.J. Unreplicated DNA remaining from unperturbed S phases passes through mitosis for resolution in daughter cells. Proc. Natl. Acad. Sci. USA 2016, 113, E5757-E5764. [CrossRef] [PubMed]

57. Torres-Rosell, J.; De Piccoli, G.; Cordón-Preciado, V.; Farmer, S.; Jarmuz, A.; Machín, F.; Pasero, P.; Lisby, M.; Haber, J.E.; Aragón, L. Anaphase onset before complete DNA replication with intact checkpoint responses. Science 2007, 315, 1411-1415. [CrossRef] [PubMed]

58. Baumann, C.; Körner, R.; Hofmann, K.; Nigg, E.A. PICH, a centromere-associated SNF2 family ATPase, is regulated by Plk1 and required for the spindle checkpoint. Cell 2007, 128, 101-114. [CrossRef] [PubMed]

59. Chan, K.-L.; North, P.S.; Hickson, I.D. BLM is required for faithful chromosome segregation and its localization defines a class of ultrafine anaphase bridges. EMBO J. 2007, 26, 3397-3409. [CrossRef] [PubMed]

60. Naim, V.; Rosselli, F. The FANC pathway and BLM collaborate during mitosis to prevent micro-nucleation and chromosome abnormalities. Nat. Cell Biol. 2009, 11, 761-768. [CrossRef]

61. Fernández-Casañas, M.; Chan, K.-L. The Unresolved Problem of DNA Bridging. Genes 2018, 9, 623. [CrossRef]

62. Glover, T.W.; Wilson, T.E.; Arlt, M.F. Fragile sites in cancer: more than meets the eye. Nat. Rev. Cancer 2017, 17, 489-501. [CrossRef] [PubMed]

63. Glover, T.W.; Berger, C.; Coyle, J.; Echo, B. DNA polymerase $\alpha$ inhibition by aphidicolin induces gaps and breaks at common fragile sites in human chromosomes. Hum. Genet. 1984, 67, 136-142. [CrossRef]

64. Durkin, S.G.; Ragland, R.L.; Arlt, M.F.; Mulle, J.G.; Warren, S.T.; Glover, T.W. Replication stress induces tumor-like microdeletions in FHIT/FRA3B. Proc. Natl. Acad. Sci. USA 2008, 105, 246-251. [CrossRef] [PubMed]

65. Arlt, M.F.; Mulle, J.G.; Schaibley, V.M.; Ragland, R.L.; Durkin, S.G.; Warren, S.T.; Glover, T.W. Replication stress induces genome-wide copy number changes in human cells that resemble polymorphic and pathogenic variants. Am. J. Hum. Genet. 2009, 84, 339-350. [CrossRef] [PubMed]

66. Le Beau, M.M.; Rassool, F.V.; Neilly, M.E.; Espinosa, R.; Glover, T.W.; Smith, D.I.; McKeithan, T.W. Replication of a common fragile site, FRA3B, occurs late in $\mathrm{S}$ phase and is delayed further upon induction: implications for the mechanism of fragile site induction. Hum. Mol. Genet. 1998, 7, 755-761. [CrossRef] [PubMed]

67. Wilson, T.E.; Arlt, M.F.; Park, S.H.; Rajendran, S.; Paulsen, M.; Ljungman, M.; Glover, T.W. Large transcription units unify copy number variants and common fragile sites arising under replication stress. Genome Res. 2015, 25, 189-200. [CrossRef]

68. Le Tallec, B.; Millot, G.A.; Blin, M.E.; Brison, O.; Dutrillaux, B.; Debatisse, M. Common fragile site profiling in epithelial and erythroid cells reveals that most recurrent cancer deletions lie in fragile sites hosting large genes. Cell Rep. 2013, 4, 420-428. [CrossRef]

69. West, S.C. Processing of recombination intermediates by the RuvABC proteins. Annu. Rev. Genet. 1997, 31, 213-244. [CrossRef]

70. Kim, S.M.; Forsburg, S.L. Regulation of structure-specific endonucleases in replication stress. Genes 2018, 9, 634. [CrossRef]

71. Lee, S.-H.; Princz, L.N.; Klügel, M.F.; Habermann, B.; Pfander, B.; Biertümpfel, C. Human Holliday junction resolvase GEN1 uses a chromodomain for efficient DNA recognition and cleavage. eLife 2015, 4, 213. [CrossRef] [PubMed]

72. Guervilly, J.-H.; Takedachi, A.; Naim, V.; Scaglione, S.; Chawhan, C.; Lovera, Y.; Despras, E.; Kuraoka, I.; Kannouche, P.; Rosselli, F.; et al. The SLX4 complex is a SUMO E3 ligase that impacts on replication stress outcome and genome stability. Mol. Cell 2015, 57, 123-137. [CrossRef] 
73. Mullen, J.R.; Kaliraman, V.; Ibrahim, S.S.; Brill, S.J. Requirement for three novel protein complexes in the absence of the Sgs1 DNA helicase in Saccharomyces cerevisiae. Genetics 2001, 157, 103-118. [PubMed]

74. Fabre, F.; Chan, A.; Heyer, W.-D.; Gangloff, S. Alternate pathways involving Sgs1/Top3, Mus81/ Mms4, and Srs2 prevent formation of toxic recombination intermediates from single-stranded gaps created by DNA replication. Proc. Natl. Acad. Sci. USA 2002, 99, 16887-16892. [CrossRef] [PubMed]

75. Newman, M.; Murray-Rust, J.; Lally, J.; Rudolf, J.; Fadden, A.; Knowles, P.P.; White, M.F.; McDonald, N.Q. Structure of an XPF endonuclease with and without DNA suggests a model for substrate recognition. EMBO J. 2005, 24, 895-905. [CrossRef]

76. Nishino, T.; Komori, K.; Ishino, Y.; Morikawa, K. Structural and functional analyses of an archaeal XPF/Rad1/Mus81 nuclease: asymmetric DNA binding and cleavage mechanisms. Structure 2005, 13, 1183-1192. [CrossRef] [PubMed]

77. Ciccia, A.; Constantinou, A.; West, S.C. Identification and characterization of the human mus81-eme1 endonuclease. J. Biol. Chem. 2003, 278, 25172-25178. [CrossRef] [PubMed]

78. Ciccia, A.; Ling, C.; Coulthard, R.; Yan, Z.; Xue, Y.; Meetei, A.R.; Laghmani, E.H.; Joenje, H.; McDonald, N.; de Winter, J.P.; et al. Identification of FAAP24, a Fanconi anemia core complex protein that interacts with FANCM. Mol. Cell 2007, 25, 331-343. [CrossRef] [PubMed]

79. Boddy, M.N.; Gaillard, P.H.; McDonald, W.H.; Shanahan, P.; Yates, J.R.; Russell, P. Mus81-Eme1 are essential components of a Holliday junction resolvase. Cell 2001, 107, 537-548. [CrossRef]

80. Kaliraman, V.; Mullen, J.R.; Fricke, W.M.; Bastin-Shanower, S.A.; Brill, S.J. Functional overlap between Sgs1-Top3 and the Mms4-Mus81 endonuclease. Genes Dev. 2001, 15, 2730-2740. [CrossRef]

81. Chen, X.B.; Melchionna, R.; Denis, C.M.; Gaillard, P.H.; Blasina, A.; Van de Weyer, I.; Boddy, M.N.; Russell, P.; Vialard, J.; McGowan, C.H. Human Mus81-associated endonuclease cleaves Holliday junctions in vitro. Mol. Cell 2001, 8, 1117-1127. [CrossRef]

82. Oğrünç, M.; Sancar, A. Identification and characterization of human MUS81-MMS4 structure-specific endonuclease. J. Biol. Chem. 2003, 278, 21715-21720. [CrossRef] [PubMed]

83. Fricke, W.M.; Bastin-Shanower, S.A.; Brill, S.J. Substrate specificity of the Saccharomyces cerevisiae Mus81-Mms4 endonuclease. DNA Repair 2005, 4, 243-251. [CrossRef] [PubMed]

84. Ehmsen, K.T.; Heyer, W.-D. A junction branch point adjacent to a DNA backbone nick directs substrate cleavage by Saccharomyces cerevisiae Mus81-Mms4. Nucleic Acids Res. 2009, 37, 2026-2036. [CrossRef] [PubMed]

85. Amangyeld, T.; Shin, Y.-K.; Lee, M.; Kwon, B.; Seo, Y.-S. Human MUS81-EME2 can cleave a variety of DNA structures including intact Holliday junction and nicked duplex. Nucleic Acids Res. 2014, 42, 5846-5862. [CrossRef]

86. Pepe, A.; West, S.C. Substrate specificity of the MUS81-EME2 structure selective endonuclease. Nucleic Acids Res. 2014, 42, 3833-3845. [CrossRef]

87. Pepe, A.; West, S.C. MUS81-EME2 promotes replication fork restart. Cell Rep. 2014, 7, 1048-1055. [CrossRef] [PubMed]

88. Matos, J.; Blanco, M.G.; Maslen, S.; Skehel, J.M.; West, S.C. Regulatory control of the resolution of DNA recombination intermediates during meiosis and mitosis. Cell 2011, 147, 158-172. [CrossRef] [PubMed]

89. Dehé, P.-M.; Coulon, S.; Scaglione, S.; Shanahan, P.; Takedachi, A.; Wohlschlegel, J.A.; Yates, J.R.; Llorente, B.; Russell, P.; Gaillard, P.-H.L. Regulation of Mus81-Eme1 Holliday junction resolvase in response to DNA damage. Nat. Struct. Mol. Biol. 2013, 20, 598-603. [CrossRef]

90. Gallo-Fernández, M.; Saugar, I.; Ortiz-Bazán, M.Á.; Vázquez, M.V.; Tercero, J.A. Cell cycle-dependent regulation of the nuclease activity of Mus81-Eme1/Mms4. Nucleic Acids Res. 2012, 40, 8325-8335. [CrossRef] [PubMed]

91. Princz, L.N.; Wild, P.; Bittmann, J.; Aguado, F.J.; Blanco, M.G.; Matos, J.; Pfander, B. Dbf4-dependent kinase and the Rtt107 scaffold promote Mus81-Mms4 resolvase activation during mitosis. EMBO J. 2017, 36, 664-678. [CrossRef] [PubMed]

92. Matos, J.; Blanco, M.G.; West, S.C. Cell-cycle kinases coordinate the resolution of recombination intermediates with chromosome segregation. Cell Rep. 2013, 4, 76-86. [CrossRef] [PubMed]

93. Szakal, B.; Branzei, D. Premature Cdk1/Cdc5/Mus81 pathway activation induces aberrant replication and deleterious crossover. EMBO J. 2013, 32, 1155-1167. [CrossRef] [PubMed] 
94. Sebesta, M.; Urulangodi, M.; Stefanovie, B.; Szakal, B.; Pacesa, M.; Lisby, M.; Branzei, D.; Krejci, L. Esc2 promotes Mus81 complex-activity via its SUMO-like and DNA binding domains. Nucleic Acids Res. 2017, 45, 215-230. [CrossRef] [PubMed]

95. Sisakova, A.; Altmannova, V.; Sebesta, M.; Krejci, L. Role of PCNA and RFC in promoting Mus81-complex activity. BMC Biol. 2017, 15, 90. [CrossRef] [PubMed]

96. Wyatt, H.D.M.; Sarbajna, S.; Matos, J.; West, S.C. Coordinated actions of SLX1-SLX4 and MUS81-EME1 for Holliday Junction resolution in human Cells. Mol. Cell 2013, 52, 234-247. [CrossRef]

97. Duda, H.; Arter, M.; Gloggnitzer, J.; Teloni, F.; Wild, P.; Blanco, M.G.; Altmeyer, M.; Matos, J. A Mechanism for controlled breakage of under-replicated chromosomes during mitosis. Dev. Cell 2016, 39, 740-755. [CrossRef]

98. Fekairi, S.; Scaglione, S.; Chahwan, C.; Taylor, E.R.; Tissier, A.; Coulon, S.; Dong, M.-Q.; Ruse, C.; Yates, J.R.; Russell, P.; et al. Human SLX4 is a Holliday junction resolvase subunit that binds multiple DNA repair/recombination endonucleases. Cell 2009, 138, 78-89. [CrossRef] [PubMed]

99. Muñoz, I.M.; Hain, K.; Déclais, A.-C.; Gardiner, M.; Toh, G.W.; Sanchez-Pulido, L.; Heuckmann, J.M.; Toth, R.; Macartney, T.; Eppink, B.; et al. Coordination of structure-specific nucleases by human SLX4/BTBD12 is required for DNA repair. Mol. Cell 2009, 35, 116-127. [CrossRef]

100. Svendsen, J.M.; Smogorzewska, A.; Sowa, M.E.; O'Connell, B.C.; Gygi, S.P.; Elledge, S.J.; Harper, J.W. Mammalian BTBD12/SLX4 assembles a Holliday junction resolvase and is required for DNA repair. Cell 2009, 138, 63-77. [CrossRef]

101. Wyatt, H.D.M.; Laister, R.C.; Martin, S.R.; Arrowsmith, C.H.; West, S.C. The SMX DNA repair Tri-nuclease. Mol. Cell 2017, 65, 848-860. [CrossRef] [PubMed]

102. Yin, J.; Wan, B.; Sarkar, J.; Horvath, K.; Wu, J.; Chen, Y.; Cheng, G.; Wan, K.; Chin, P.; Lei, M.; et al. Dimerization of SLX4 contributes to functioning of the SLX4-nuclease complex. Nucleic Acids Res. 2016, 44, 4871-4880. [CrossRef]

103. Coulon, S.; Gaillard, P.-H.L.; Chahwan, C.; McDonald, W.H.; Yates, J.R.; Russell, P. Slx1-Slx4 are subunits of a structure-specific endonuclease that maintains ribosomal DNA in fission yeast. Mol. Biol. Cell 2004, 15, 71-80. [CrossRef]

104. Fricke, W.M.; Brill, S.J. Slx1-Slx4 is a second structure-specific endonuclease functionally redundant with Sgs1-Top3. Genes Dev. 2003, 17, 1768-1778. [CrossRef]

105. Kaliraman, V.; Brill, S.J. Role of SGS1 and SLX4 in maintaining rDNA structure in Saccharomyces cerevisiae. Curr. Genet. 2002, 41, 389-400. [CrossRef]

106. Coulon, S.; Noguchi, E.; Noguchi, C.; Du, L.-L.; Nakamura, T.M.; Russell, P. Rad22Rad52-dependent repair of ribosomal DNA repeats cleaved by Slx1-Slx4 endonuclease. Mol. Biol. Cell 2006, 17, 2081-2090. [CrossRef] [PubMed]

107. Sarbajna, S.; Davies, D.; West, S.C. Roles of SLX1-SLX4, MUS81-EME1, and GEN1 in avoiding genome instability and mitotic catastrophe. Genes Dev. 2014, 28, 1124-1136. [CrossRef]

108. Garner, E.; Kim, Y.; Lach, F.P.; Kottemann, M.C.; Smogorzewska, A. Human GEN1 and the SLX4-associated nucleases MUS81 and SLX1 are essential for the resolution of replication-induced Holliday junctions. Cell Rep. 2013, 5, 207-215. [CrossRef]

109. Guervilly, J.-H.; Gaillard, P.H. SLX4: Multitasking to maintain genome stability. Crit. Rev. Biochem. Mol. Biol. 2018, 53, 475-514. [CrossRef] [PubMed]

110. Kim, Y.; Lach, F.P.; Desetty, R.; Hanenberg, H.; Auerbach, A.D.; Smogorzewska, A. Mutations of the SLX4 gene in Fanconi anemia. Nat. Genet. 2011, 43, 142-146. [CrossRef]

111. Stoepker, C.; Hain, K.; Schuster, B.; Hilhorst-Hofstee, Y.; Rooimans, M.A.; Steltenpool, J.; Oostra, A.B.; Eirich, K.; Korthof, E.T.; Nieuwint, A.W.M.; et al. SLX4, a coordinator of structure-specific endonucleases, is mutated in a new Fanconi anemia subtype. Nat. Genet. 2011, 43, 138-141. [CrossRef] [PubMed]

112. Gaur, V.; Wyatt, H.D.M.; Komorowska, W.; Szczepanowski, R.H.; de Sanctis, D.; Gorecka, K.M.; West, S.C.; Nowotny, M. Structural and mechanistic analysis of the Slx1-Slx4 endonuclease. Cell Rep. 2015, 10, 1467-1476. [CrossRef]

113. Castor, D.; Nair, N.; Déclais, A.-C.; Lachaud, C.; Toth, R.; Macartney, T.J.; Lilley, D.M.J.; Arthur, J.S.C.; Rouse, J. Cooperative control of holliday junction resolution and DNA repair by the SLX1 and MUS81-EME1 nucleases. Mol. Cell 2013, 52, 221-233. [CrossRef] [PubMed] 
114. Gwon, G.H.; Jo, A.; Baek, K.; Jin, K.S.; Fu, Y.; Lee, J.-B.; Kim, Y.; Cho, Y. Crystal structures of the structure-selective nuclease Mus81-Eme1 bound to flap DNA substrates. EMBO J. 2014, 33, 1061-1072. [CrossRef] [PubMed]

115. Palma, A.; Pugliese, G.M.; Murfuni, I.; Marabitti, V.; Malacaria, E.; Rinalducci, S.; Minoprio, A.; Sanchez, M.; Mazzei, F.; Zolla, L.; et al. Phosphorylation by CK2 regulates MUS81/EME1 in mitosis and after replication stress. Nucleic Acids Res. 2018, 46, 5109-5124. [CrossRef]

116. Saugar, I.; Jiménez-Martín, A.; Tercero, J.A. Subnuclear relocalization of structure-specific endonucleases in response to DNA damage. Cell Rep. 2017, 20, 1553-1562. [CrossRef]

117. Schwartz, E.K.; Wright, W.D.; Ehmsen, K.T.; Evans, J.E.; Stahlberg, H.; Heyer, W.-D. Mus81-Mms4 functions as a single heterodimer to cleave nicked intermediates in recombinational DNA repair. Mol. Cell. Biol. 2012, 32, 3065-3080. [CrossRef] [PubMed]

118. Ohouo, P.Y.; Bastos de Oliveira, F.M.; Almeida, B.S.; Smolka, M.B. DNA damage signaling recruits the Rtt107-Slx4 scaffolds via Dpb11 to mediate replication stress response. Mol. Cell 2010, 39, 300-306. [CrossRef]

119. Gritenaite, D.; Princz, L.N.; Szakal, B.; Bantele, S.C.S.; Wendeler, L.; Schilbach, S.; Habermann, B.H.; Matos, J.; Lisby, M.; Branzei, D.; et al. A cell cycle-regulated Slx4-Dpb11 complex promotes the resolution of DNA repair intermediates linked to stalled replication. Genes Dev. 2014, 28, 1604-1619. [CrossRef] [PubMed]

120. Princz, L.N.; Gritenaite, D.; Pfander, B. The Slx4-Dpb11 scaffold complex: coordinating the response to replication fork stalling in S-phase and the subsequent mitosis. Cell Cycle 2014, 14, 488-494. [CrossRef]

121. Ip, S.C.Y.; Rass, U.; Blanco, M.G.; Flynn, H.R.; Skehel, J.M.; West, S.C. Identification of Holliday junction resolvases from humans and yeast. Nature 2008, 456, 357-361. [CrossRef]

122. West, S.C. The search for a human Holliday junction resolvase. Biochem. Soc. Trans. 2009, 37, 519-526. [CrossRef]

123. Lieber, M.R. The FEN-1 family of structure-specific nucleases in eukaryotic DNA replication, recombination and repair. Bioessays 1997, 19, 233-240. [CrossRef]

124. Bailly, A.P.; Freeman, A.; Hall, J.; Déclais, A.-C.; Alpi, A.; Lilley, D.M.J.; Ahmed, S.; Gartner, A. The Caenorhabditis elegans homolog of Gen1/Yen1 resolvases links DNA damage signaling to DNA double-strand break repair. PLoS Genet. 2010, 6, e1001025. [CrossRef]

125. Yang, Y.; Ishino, S.; Yamagami, T.; Kumamaru, T.; Satoh, H.; Ishino, Y. The OsGEN-L protein from Oryza sativa possesses Holliday junction resolvase activity as well as 5'-flap endonuclease activity. J. Biochem. 2012, 151, 317-327. [CrossRef]

126. Bauknecht, M.; Kobbe, D. AtGEN1 and AtSEND1, two paralogs in Arabidopsis, possess Holliday junction resolvase activity. Plant Physiol. 2014, 166, 202-216. [CrossRef] [PubMed]

127. Andersen, S.L.; Kuo, H.K.; Savukoski, D.; Brodsky, M.H.; Sekelsky, J. Three structure-selective endonucleases are essential in the absence of BLM helicase in Drosophila. PLoS Genet. 2011, 7, e1002315. [CrossRef]

128. Lorenz, A.; West, S.C.; Whitby, M.C. The human Holliday junction resolvase GEN1 rescues the meiotic phenotype of a Schizosaccharomyces pombe mus81 mutant. Nucleic Acids Res. 2010, 38, 1866-1873. [CrossRef]

129. Freeman, A.D.J.; Liu, Y.; Déclais, A.-C.; Gartner, A.; Lilley, D.M.J. GEN1 from a thermophilic fungus is functionally closely similar to non-eukaryotic junction-resolving enzymes. J. Mol. Biol. 2014, 426, 3946-3959. [CrossRef] [PubMed]

130. Shah Punatar, R.; Martin, M.J.; Wyatt, H.D.M.; Chan, Y.W.; West, S.C. Resolution of single and double Holliday junction recombination intermediates by GEN1. Proc. Natl. Acad. Sci. USA 2017, 114, 443-450. [CrossRef] [PubMed]

131. Rass, U.; Compton, S.A.; Matos, J.; Singleton, M.R.; Ip, S.C.Y.; Blanco, M.G.; Griffith, J.D.; West, S.C. Mechanism of Holliday junction resolution by the human GEN1 protein. Genes Dev. 2010, 24, 1559-1569. [CrossRef] [PubMed]

132. Chan, Y.W.; West, S. GEN1 promotes Holliday junction resolution by a coordinated nick and counter-nick mechanism. Nucleic Acids Res. 2015, 43, 10882-10892. [CrossRef] [PubMed]

133. Liu, Y.; Freeman, A.D.J.; Déclais, A.-C.; Wilson, T.J.; Gartner, A.; Lilley, D.M.J. Crystal structure of a eukaryotic GEN1 resolving enzyme bound to DNA. Cell Rep. 2015, 13, 2565-2575. [CrossRef] [PubMed]

134. Sobhy, M.A.; Bralic, A.; Raducanu, V.-S.; Takahashi, M.; Tehseen, M.; Rashid, F.; Zaher, M.S.; Hamdan, S.M. Resolution of the Holliday junction recombination intermediate by human GEN1 at the single-molecule level. Nucleic Acids Res. 2018, 5, 282. [CrossRef] [PubMed]

135. Blanco, M.G.; Matos, J.; West, S.C. Dual control of Yen1 nuclease activity and cellular localization by Cdk and Cdc14 prevents genome instability. Mol. Cell 2014, 54, 94-106. [CrossRef] 
136. García-Luis, J.; Clemente-Blanco, A.; Aragón, L.; Machín, F. Cdc14 targets the Holliday junction resolvase Yen1 to the nucleus in early anaphase. Cell Cycle 2014, 13, 1392-1399. [CrossRef] [PubMed]

137. Kosugi, S.; Hasebe, M.; Tomita, M.; Yanagawa, H. Systematic identification of cell cycle-dependent yeast nucleocytoplasmic shuttling proteins by prediction of composite motifs. Proc. Natl. Acad. Sci. USA 2009, 106, 10171-10176. [CrossRef] [PubMed]

138. Talhaoui, I.; Bernal, M.; Mullen, J.R.; Dorison, H.; Palancade, B.; Brill, S.J.; Mazón, G. Slx5-Slx8 ubiquitin ligase targets active pools of the Yen1 nuclease to limit crossover formation. Nat. Commun. 2018, 9, 5016. [CrossRef]

139. Chan, Y.W.; West, S.C. Spatial control of the GEN1 Holliday junction resolvase ensures genome stability. Nat. Commun. 2014, 5, 4844. [CrossRef] [PubMed]

140. Ait Saada, A.; Lambert, S.A.E.; Carr, A.M. Preserving replication fork integrity and competence via the homologous recombination pathway. DNA Repair 2018, 71, 135-147. [CrossRef] [PubMed]

141. Branzei, D.; Szakal, B. DNA damage tolerance by recombination: Molecular pathways and DNA structures. DNA Repair 2016, 44, 68-75. [CrossRef] [PubMed]

142. Agmon, N.; Yovel, M.; Harari, Y.; Liefshitz, B.; Kupiec, M. The role of Holliday junction resolvases in the repair of spontaneous and induced DNA damage. Nucleic Acids Res. 2011, 39, 7009-7019. [CrossRef] [PubMed]

143. Blanco, M.G.; Matos, J.; Rass, U.; Ip, S.C.Y.; West, S.C. Functional overlap between the structure-specific nucleases Yen1 and Mus81-Mms4 for DNA-damage repair in S. cerevisiae. DNA Repair 2010, 9, 394-402. [CrossRef]

144. Ho, C.K.; Mazón, G.; Lam, A.F.; Symington, L.S. Mus81 and Yen1 promote reciprocal exchange during mitotic recombination to maintain genome integrity in budding yeast. Mol. Cell 2010, 40, 988-1000. [CrossRef]

145. Tay, Y.D.; Wu, L. Overlapping roles for Yen1 and Mus81 in cellular Holliday junction processing. J. Biol. Chem. 2010, 285, 11427-11432. [CrossRef] [PubMed]

146. Boddy, M.N.; Lopez-Girona, A.; Shanahan, P.; Interthal, H.; Heyer, W.D.; Russell, P. Damage tolerance protein Mus81 associates with the FHA1 domain of checkpoint kinase Cds1. Mol. Cell. Biol. 2000, 20, 8758-8766. [CrossRef]

147. García-Luis, J.; Machín, F. Mus81-Mms4 and Yen1 resolve a novel anaphase bridge formed by noncanonical Holliday junctions. Nat. Commun. 2014, 5, 5652. [CrossRef]

148. Ying, S.; Minocherhomji, S.; Chan, K.-L.; Palmai-Pallag, T.; Chu, W.K.; Wass, T.; Mankouri, H.W.; Liu, Y.; Hickson, I.D. MUS81 promotes common fragile site expression. Nat. Cell Biol. 2013, 15, 1001-1007. [CrossRef] [PubMed]

149. Naim, V.; Wilhelm, T.; Debatisse, M.; Rosselli, F. ERCC1 and MUS81-EME1 promote sister chromatid separation by processing late replication intermediates at common fragile sites during mitosis. Nat. Cell Biol. 2013, 15, 1008-1015. [CrossRef]

150. Chan, Y.W.; Fugger, K.; West, S.C. Unresolved recombination intermediates lead to ultra-fine anaphase bridges, chromosome breaks and aberrations. Nat. Cell Biol. 2018, 20, 92-103. [CrossRef] [PubMed]

151. Eissler, C.L.; Mazón, G.; Powers, B.L.; Savinov, S.N.; Symington, L.S.; Hall, M.C. The Cdk/cDc14 module controls activation of the Yen1 Holliday junction resolvase to promote genome stability. Mol. Cell 2014, 54, 80-93. [CrossRef]

152. Bizard, A.H.; Hickson, I.D. The dissolution of double Holliday junctions. Cold Spring Harb. Perspect. Biol. 2014, 6, a016477. [CrossRef] [PubMed]

153. Técher, H.; Koundrioukoff, S.; Carignon, S.; Wilhelm, T.; Millot, G.A.; Lopez, B.S.; Brison, O.; Debatisse, M. Signaling from Mus81-Eme2-dependent DNA damage elicited by Chk1 deficiency modulates replication fork speed and origin usage. Cell Rep. 2016, 14, 1114-1127. [CrossRef] [PubMed]

154. Forment, J.V.; Blasius, M.; Guerini, I.; Jackson, S.P. Structure-specific DNA endonuclease Mus81/Eme1 generates DNA damage caused by Chk1 inactivation. PLoS ONE 2011, 6, e23517. [CrossRef] [PubMed]

155. Szmyd, R.; Niska-Blakie, J.; Diril, M.K.; Renck Nunes, P.; Tzelepis, K.; Lacroix, A.; van Hul, N.; Deng, L.-W.; Matos, J.; Dreesen, O.; et al. Premature activation of Cdk1 leads to mitotic events in S phase and embryonic lethality. Oncogene 2018, 448, 811. [CrossRef] [PubMed]

156. Beck, H.; Nähse, V.; Larsen, M.S.Y.; Groth, P.; Clancy, T.; Lees, M.; Jørgensen, M.; Helleday, T.; Syljuåsen, R.G.; Sørensen, C.S. Regulators of cyclin-dependent kinases are crucial for maintaining genome integrity in S phase. J. Cell Biol. 2010, 188, 629-638. [CrossRef] 
157. Beck, H.; Nähse-Kumpf, V.; Larsen, M.S.Y.; O’Hanlon, K.A.; Patzke, S.; Holmberg, C.; Mejlvang, J.; Groth, A.; Nielsen, O.; Syljuåsen, R.G.; et al. Cyclin-dependent kinase suppression by WEE1 kinase protects the genome through control of replication initiation and nucleotide consumption. Mol. Cell. Biol. 2012, 32, 4226-4236. [CrossRef]

158. Domínguez-Kelly, R.; Martín, Y.; Koundrioukoff, S.; Tanenbaum, M.E.; Smits, V.A.J.; Medema, R.H.; Debatisse, M.; Freire, R. Wee1 controls genomic stability during replication by regulating the Mus81-Eme1 endonuclease. J. Cell Biol. 2011, 194, 567-579. [CrossRef]

159. Hanada, K.; Budzowska, M.; Davies, S.L.; van Drunen, E.; Onizawa, H.; Beverloo, H.B.; Maas, A.; Essers, J.; Hickson, I.D.; Kanaar, R. The structure-specific endonuclease Mus81 contributes to replication restart by generating double-strand DNA breaks. Nat. Struct. Mol. Biol. 2007, 14, 1096-1104. [CrossRef]

160. Hanada, K.; Budzowska, M.; Modesti, M.; Maas, A.; Wyman, C.; Essers, J.; Kanaar, R. The structure-specific endonuclease Mus81-Eme1 promotes conversion of interstrand DNA crosslinks into double-strands breaks. EMBO J. 2006, 25, 4921-4932. [CrossRef]

161. Kramara, J.; Osia, B.; Malkova, A. Break-induced replication: The where, the why, and the how. Trends Genet. 2018, 34, 518-531. [CrossRef]

162. Xu, Y.; Ning, S.; Wei, Z.; Xu, R.; Xu, X.; Xing, M.; Guo, R.; Xu, D. 53BP1 and BRCA1 control pathway choice for stalled replication restart. eLlife 2017, 6, 35897. [CrossRef]

163. Shimura, T.; Torres, M.J.; Martin, M.M.; Rao, V.A.; Pommier, Y.; Katsura, M.; Miyagawa, K.; Aladjem, M.I. Bloom's syndrome helicase and Mus81 are required to induce transient double-strand DNA breaks in response to DNA replication stress. J. Mol. Biol. 2008, 375, 1152-1164. [CrossRef] [PubMed]

164. Regairaz, M.; Zhang, Y.-W.; Fu, H.; Agama, K.K.; Tata, N.; Agrawal, S.; Aladjem, M.I.; Pommier, Y. Mus81-mediated DNA cleavage resolves replication forks stalled by topoisomerase I-DNA complexes. J. Cell Biol. 2011, 195, 739-749. [CrossRef] [PubMed]

165. Murfuni, I.; Nicolai, S.; Baldari, S.; Crescenzi, M.; Bignami, M.; Franchitto, A.; Pichierri, P. The WRN and MUS81 proteins limit cell death and genome instability following oncogene activation. Oncogene 2013, 32, 610-620. [CrossRef] [PubMed]

166. Shimura, T.; Ochiai, Y.; Noma, N.; Oikawa, T.; Sano, Y.; Fukumoto, M. Cyclin D1 overexpression perturbs DNA replication and induces replication-associated DNA double-strand breaks in acquired radioresistant cells. Cell Cycle 2013, 12, 773-782. [CrossRef]

167. Lai, X.; Broderick, R.; Bergoglio, V.; Zimmer, J.; Badie, S.; Niedzwiedz, W.; Hoffmann, J.-S.; Tarsounas, M. MUS81 nuclease activity is essential for replication stress tolerance and chromosome segregation in BRCA2-deficient cells. Nat. Commun. 2017, 8, 15983. [CrossRef]

168. Fugger, K.; Chu, W.K.; Haahr, P.; Kousholt, A.N.; Beck, H.; Payne, M.J.; Hanada, K.; Hickson, I.D.; Sørensen, C.S. FBH1 co-operates with MUS81 in inducing DNA double-strand breaks and cell death following replication stress. Nat. Commun. 2013, 4, 1423. [CrossRef]

169. Kurashima, K.; Sekimoto, T.; Oda, T.; Kawabata, T.; Hanaoka, F.; Yamashita, T. Poln, a Y-family translesion synthesis polymerase, promotes cellular tolerance of Myc-induced replication stress. J. Cell. Sci. 2018, 131, jcs212183. [CrossRef]

170. Mayle, R.; Campbell, I.M.; Beck, C.R.; Yu, Y.; Wilson, M.; Shaw, C.A.; Bjergbaek, L.; Lupski, J.R.; Ira, G. Mus81 and converging forks limit the mutagenicity of replication fork breakage. Science 2015, 349, 742-747. [CrossRef] [PubMed]

171. Macheret, M.; Halazonetis, T.D. DNA replication stress as a hallmark of cancer. Annu. Rev. Pathol. 2015, 10, 425-448. [CrossRef]

172. Chan, Y.W.; West, S.C. A new class of ultrafine anaphase bridges generated by homologous recombination. Cell Cycle 2018, 17, 2101-2109. [CrossRef] [PubMed]

173. Tiwari, A.; Addis Jones, O.; Chan, K.-L. 53BP1 can limit sister-chromatid rupture and rearrangements driven by a distinct ultrafine DNA bridging-breakage process. Nat. Commun. 2018, 9, 677. [CrossRef] [PubMed]

174. Chan, K.-L.; Palmai-Pallag, T.; Ying, S.; Hickson, I.D. Replication stress induces sister-chromatid bridging at fragile site loci in mitosis. Nat. Cell Biol. 2009, 11, 753-760. [CrossRef] [PubMed]

175. Minocherhomji, S.; Ying, S.; Bjerregaard, V.A.; Bursomanno, S.; Aleliunaite, A.; Wu, W.; Mankouri, H.W.; Shen, H.; Liu, Y.; Hickson, I.D. Replication stress activates DNA repair synthesis in mitosis. Nature 2015, 528, 286-290. [CrossRef] 
176. Di Marco, S.; Hasanova, Z.; Kanagaraj, R.; Chappidi, N.; Altmannova, V.; Menon, S.; Sedlackova, H.; Langhoff, J.; Surendranath, K.; Hühn, D.; Bhowmick, R.; Marini, V.; Ferrari, S.; Hickson, I.D.; et al. RECQ5 helicase cooperates with MUS81 endonuclease in processing stalled replication forks at common fragile sites during mitosis. Mol. Cell 2017, 66, 658-671. [CrossRef]

177. Bhowmick, R.; Minocherhomji, S.; Hickson, I.D. RAD52 facilitates mitotic DNA synthesis following replication stress. Mol. Cell 2016, 64, 1117-1126. [CrossRef]

178. Downing, B.; Morgan, R.; VanHulle, K.; Deem, A.; Malkova, A. Large inverted repeats in the vicinity of a single double-strand break strongly affect repair in yeast diploids lacking Rad51. Mutat. Res. 2008, 645, 9-18. [CrossRef]

179. Hastings, P.J.; Ira, G.; Lupski, J.R. A microhomology-mediated break-induced replication model for the origin of human copy number variation. PLoS Genet. 2009, 5, e1000327. [CrossRef]

180. Ottaviani, D.; LeCain, M.; Sheer, D. The role of microhomology in genomic structural variation. Trends Genet. 2014, 30, 85-94. [CrossRef] [PubMed]

181. Sakofsky, C.J.; Malkova, A. Break induced replication in eukaryotes: mechanisms, functions, and consequences. Crit. Rev. Biochem. Mol. Biol. 2017, 52, 395-413. [CrossRef] [PubMed]

182. Özer, Ö.; Bhowmick, R.; Liu, Y.; Hickson, I.D. Human cancer cells utilize mitotic DNA synthesis to resist replication stress at telomeres regardless of their telomere maintenance mechanism. Oncotarget 2018, 9, 15836-15846. [CrossRef]

183. Budd, M.E.; Tong, A.H.Y.; Polaczek, P.; Peng, X.; Boone, C.; Campbell, J.L. A network of multi-tasking proteins at the DNA replication fork preserves genome stability. PLoS Genet. 2005, 1, e61. [CrossRef] [PubMed]

184. Falquet, B.; Rass, U. A new role for Holliday junction resolvase Yen1 in processing DNA replication intermediates exposes Dna2 as an accessory replicative helicase. Microb. Cell 2017, 4, 32-34. [CrossRef] [PubMed]

185. Ölmezer, G.; Levikova, M.; Klein, D.; Falquet, B.; Fontana, G.A.; Cejka, P.; Rass, U. Replication intermediates that escape Dna2 activity are processed by Holliday junction resolvase Yen1. Nat. Commun. 2016, 7, 13157. [CrossRef]

186. Duxin, J.P.; Dao, B.; Martinsson, P.; Rajala, N.; Guittat, L.; Campbell, J.L.; Spelbrink, J.N.; Stewart, S.A. Human Dna2 is a nuclear and mitochondrial DNA maintenance protein. Mol. Cell. Biol. 2009, 29, 4274-4282. [CrossRef] [PubMed]

187. Duxin, J.P.; Moore, H.R.; Sidorova, J.; Karanja, K.; Honaker, Y.; Dao, B.; Piwnica-Worms, H.; Campbell, J.L.; Monnat, R.J.; Stewart, S.A. Okazaki fragment processing-independent role for human Dna2 enzyme during DNA replication. J. Biol. Chem. 2012, 287, 21980-21991. [CrossRef]

188. Thangavel, S.; Berti, M.; Levikova, M.; Pinto, C.; Gomathinayagam, S.; Vujanovic, M.; Zellweger, R.; Moore, H.; Lee, E.H.; Hendrickson, E.A.; et al. DNA2 drives processing and restart of reversed replication forks in human cells. J. Cell Biol. 2015, 208, 545-562. [CrossRef]

189. Li, Z.; Liu, B.; Jin, W.; Wu, X.; Zhou, M.; Liu, V.Z.; Goel, A.; Shen, Z.; Zheng, L.; Shen, B. hDNA2 nuclease/helicase promotes centromeric DNA replication and genome stability. EMBO J. 2018, e96729. [CrossRef]

190. Michel, A.H.; Hatakeyama, R.; Kimmig, P.; Arter, M.; Peter, M.; Matos, J.; De Virgilio, C.; Kornmann, B. Functional mapping of yeast genomes by saturated transposition. eLife 2017, 6, E3179. [CrossRef]

191. Alderton, G.K.; Joenje, H.; Varon, R.; Børglum, A.D.; Jeggo, P.A.; O’Driscoll, M. Seckel syndrome exhibits cellular features demonstrating defects in the ATR-signalling pathway. Hum. Mol. Genet. 2004, 13, 3127-3138. [CrossRef] [PubMed]

192. Shaheen, R.; Faqeih, E.; Ansari, S.; Abdel-Salam, G.; Al-Hassnan, Z.N.; Al-Shidi, T.; Alomar, R.; Sogaty, S.; Alkuraya, F.S. Genomic analysis of primordial dwarfism reveals novel disease genes. Genome Res. 2014, 24, 291-299. [CrossRef]

193. Peng, G.; Dai, H.; Zhang, W.; Hsieh, H.-J.; Pan, M.-R.; Park, Y.-Y.; Tsai, R.Y.-L.; Bedrosian, I.; Lee, J.-S.; Ira, G.; et al. Human nuclease/helicase DNA2 alleviates replication stress by promoting DNA end resection. Cancer Res. 2012, 72, 2802-2813. [CrossRef] [PubMed]

194. Strauss, C.; Kornowski, M.; Benvenisty, A.; Shahar, A.; Masury, H.; Ben-Porath, I.; Ravid, T.; Arbel-Eden, A.; Goldberg, M. The DNA2 nuclease/helicase is an estrogen-dependent gene mutated in breast and ovarian cancers. Oncotarget 2014, 5, 9396-9409. [CrossRef] [PubMed] 
195. Neelsen, K.J.; Lopes, M. Replication fork reversal in eukaryotes: from dead end to dynamic response. Nat. Rev. Mol. Cell Biol. 2015, 16, 207-220. [CrossRef]

196. Lemaçon, D.; Jackson, J.; Quinet, A.; Brickner, J.R.; Li, S.; Yazinski, S.; You, Z.; Ira, G.; Zou, L.; Mosammaparast, N.; et al. MRE11 and EXO1 nucleases degrade reversed forks and elicit MUS81-dependent fork rescue in BRCA2-deficient cells. Nat. Commun. 2017, 8, 860. [CrossRef] [PubMed]

197. Zellweger, R.; Dalcher, D.; Mutreja, K.; Berti, M.; Schmid, J.A.; Herrador, R.; Vindigni, A.; Lopes, M. Rad51-mediated replication fork reversal is a global response to genotoxic treatments in human cells. J. Cell Biol. 2015, 208, 563-579. [CrossRef] [PubMed]

198. Quinet, A.; Lemaçon, D.; Vindigni, A. Replication fork reversal: Players and guardians. Mol. Cell 2017, 68, 830-833. [CrossRef] [PubMed]

199. Ray Chaudhuri, A.; Hashimoto, Y.; Herrador, R.; Neelsen, K.J.; Fachinetti, D.; Bermejo, R.; Cocito, A.; Costanzo, V.; Lopes, M. Topoisomerase I poisoning results in PARP-mediated replication fork reversal. Nat. Struct. Mol. Biol. 2012, 19, 417-423. [CrossRef]

200. Mutreja, K.; Krietsch, J.; Hess, J.; Ursich, S.; Berti, M.; Roessler, F.K.; Zellweger, R.; Patra, M.; Gasser, G.; Lopes, M. ATR-mediated global fork slowing and reversal assist fork traverse and prevent chromosomal breakage at DNA interstrand cross-links. Cell Rep. 2018, 24, 2629-2642. [CrossRef]

201. Menin, L.; Ursich, S.; Trovesi, C.; Zellweger, R.; Lopes, M.; Longhese, M.P.; Clerici, M. Tel1/ATM prevents degradation of replication forks that reverse after topoisomerase poisoning. EMBO Rep. 2018, 19, e45535. [CrossRef]

202. Bhat, K.P.; Krishnamoorthy, A.; Dungrawala, H.; Garcin, E.B.; Modesti, M.; Cortez, D. RADX modulates RAD51 activity to control replication fork protection. Cell Rep. 2018, 24, 538-545. [CrossRef] [PubMed]

203. Dungrawala, H.; Bhat, K.P.; Le Meur, R.; Chazin, W.J.; Ding, X.; Sharan, S.K.; Wessel, S.R.; Sathe, A.A.; Zhao, R.; Cortez, D. RADX promotes genome stability and modulates chemosensitivity by regulating RAD51 at replication forks. Mol. Cell 2017, 67, 374-386. [CrossRef]

204. Schlacher, K.; Christ, N.; Siaud, N.; Egashira, A.; Wu, H.; Jasin, M. Double-strand break repair-independent role for BRCA2 in blocking stalled replication fork degradation by MRE11. Cell 2011, 145, 529-542. [CrossRef]

205. Higgs, M.R.; Reynolds, J.J.; Winczura, A.; Blackford, A.N.; Borel, V.; Miller, E.S.; Zlatanou, A.; Nieminuszczy, J.; Ryan, E.L.; Davies, N.J.; et al. BOD1L is required to suppress deleterious resection of stressed replication forks. Mol. Cell 2015, 59, 462-477. [CrossRef] [PubMed]

206. Mijic, S.; Zellweger, R.; Chappidi, N.; Berti, M.; Jacobs, K.; Mutreja, K.; Ursich, S.; Ray Chaudhuri, A.; Nussenzweig, A.; Janscak, P.; et al. Replication fork reversal triggers fork degradation in BRCA2-defective cells. Nat. Commun. 2017, 8, 859. [CrossRef] [PubMed]

207. Przetocka, S.; Porro, A.; Bolck, H.A.; Walker, C.; Lezaja, A.; Trenner, A.; von Aesch, C.; Himmels, S.-F.; D'Andrea, A.D.; Ceccaldi, R.; et al. CtIP-mediated fork protection synergizes with BRCA1 to suppress genomic instability upon DNA replication stress. Mol. Cell 2018, 72, 568-582. [CrossRef] [PubMed]

208. Berti, M.; Ray Chaudhuri, A.; Thangavel, S.; Gomathinayagam, S.; Kenig, S.; Vujanovic, M.; Odreman, F.; Glatter, T.; Graziano, S.; Mendoza-Maldonado, R.; et al. Human RECQ1 promotes restart of replication forks reversed by DNA topoisomerase I inhibition. Nat. Struct. Mol. Biol. 2013, 20, 347-354. [CrossRef] [PubMed]

209. Manosas, M.; Perumal, S.K.; Croquette, V.; Benkovic, S.J. Direct observation of stalled fork restart via fork regression in the T4 replication system. Science 2012, 338, 1217-1220. [CrossRef]

210. Manosas, M.; Perumal, S.K.; Bianco, P.R.; Bianco, P.; Ritort, F.; Benkovic, S.J.; Croquette, V. RecG and UvsW catalyse robust DNA rewinding critical for stalled DNA replication fork rescue. Nat. Commun. 2013, 4, 2368. [CrossRef]

(C) 2019 by the authors. Licensee MDPI, Basel, Switzerland. This article is an open access article distributed under the terms and conditions of the Creative Commons Attribution (CC BY) license (http://creativecommons.org/licenses/by/4.0/). 